\title{
Late Pliocene to early Pleistocene climate dynamics in western North America based on a new pollen record from paleo-Lake Idaho
}

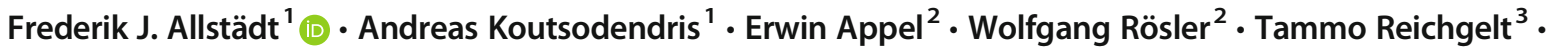 \\ Stefanie Kaboth-Bahr ${ }^{1,4}$. Alexander A. Prokopenko ${ }^{5} \cdot$ Jörg Pross $^{1}$
}

Received: 5 March 2020 /Revised: 28 July 2020 / Accepted: 21 September 2020 / Published online: 7 January 2021

(C) The Author(s) 2021

\begin{abstract}
Marked by the expansion of ice sheets in the high latitudes, the intensification of Northern Hemisphere glaciation across the Plio/ Pleistocene transition at $\sim 2.7$ Ma represents a critical interval of late Neogene climate evolution. To date, the characteristics of climate change in North America during that time and its imprint on vegetation has remained poorly constrained because of the lack of continuous, highly resolved terrestrial records. We here assess the vegetation dynamics in northwestern North America during the late Pliocene and early Pleistocene (c. 2.8-2.4 Ma) based on a pollen record from a lacustrine sequence from paleoLake Idaho, western Snake River Plain (USA) that has been retrieved within the framework of an International Continental Drilling Program (ICDP) coring campaign. Our data indicate a sensitive response of forest ecosystems to glacial/interglacial variability paced by orbital obliquity across the study interval, and also highlight a distinct expansion of steppic elements that likely occurs during the first strong glacial of the Pleistocene, i.e. Marine Isotope Stage 100. The pollen data document a major forest biome change at $\sim 2.6 \mathrm{Ma}$ that is marked by the replacement of conifer-dominated forests by open mixed forests. Quantitative pollen-based climate estimates suggest that this forest reorganisation was associated with an increase in precipitation from the late Pliocene to the early Pleistocene. We attribute this shift to an enhanced moisture transport from the subarctic Pacific Ocean to North America, confirming the hypothesis that ocean-circulation changes were instrumental in the intensification of Northern Hemisphere glaciation.
\end{abstract}

Keywords Plio/Pleistocene transition · North America · Paleo-Lake Idaho · Northern Hemisphere glaciation · Glacial/interglacial cycles $\cdot$ Climate reconstruction

This article is a contribution to the special issue "Palaeobotanical contributions in honour of Volker Mosbrugger"

Electronic supplementary material The online version of this article (https://doi.org/10.1007/s12549-020-00460-1) contains supplementary material, which is available to authorized users.

Frederik J. Allstädt

frederik.allstaedt@geow.uni-heidelberg.de

1 Institute of Earth Sciences, Heidelberg University, Im Neuenheimer Feld 234-236, 69120 Heidelberg, Germany

2 Department of Geosciences, University of Tübingen, Hölderlinstraße 12, 72074 Tübingen, Germany

3 Department of Geosciences, University of Connecticut, 354 Mansfield Road, Storrs, CT 06269, USA

4 Institute of Geosciences, University of Potsdam, Karl-Liebknecht-Straße 24-26, 14467 Potsdam-Golm, Germany

5 Institute of Geology and Mineralogy, University of Cologne, Zülpicherstr. 49a, 50674 Cologne, Germany

\section{Introduction}

The 'mid'-Pliocene to early Pleistocene time period $(\sim 3.6-$ $2.0 \mathrm{Ma}$ ) comprises the full range of climatic boundary conditions as realised in the context of present-day and near-future climate change (e.g. Robinson et al. 2008). Atmospheric carbon-dioxide concentrations $\left(p \mathrm{CO}_{2}\right)$ varied between preindustrial levels and anthropogenically perturbed values as they may be reached in few decades (Pachauri et al. 2014; Martínez-Botí et al. 2015), whereas the palaeogeography was very similar to that of today. Together, these facts make the 'mid'-Pliocene to early Pleistocene well suited to examine the response of the Earth's climate to increasing greenhousegas forcing as a consequence of anthropogenic $\mathrm{CO}_{2}$ emissions (Robinson et al. 2008; Haywood et al. 2016).

At the same time, the 'mid'-Pliocene to early Pleistocene was characterised by a highly dynamic climate evolution, with the Earth shifting from a warmer Pliocene climate state 
lacking large-scale Northern Hemisphere ice sheets to a progressively cooler Pleistocene climate state with an increasing sensitivity of the climate/cryosphere system to orbital forcing (e.g. Ravelo et al. 2004; Lisiecki and Raymo 2005; De Schepper et al. 2014). Against the background of general cooling, late Pliocene climate was punctuated by repeated early glaciation events that heralded the intensification of Northern Hemisphere glaciation (iNHG) $\sim 2.7 \mathrm{Ma}$ ago. Specifically, the glaciation connected to Marine Isotope Stage (MIS) G6 ( 2.7 Ma) is often considered to mark the onset of iNHG because it resulted in the first occurrence of ice-rafting debris (IRD) in the North Atlantic Ocean (e.g. Shackleton et al. 1984; Bailey et al. 2013). Marine Isotope Stage 100, 2.5 Ma ago, was likely the first glacial during which the Laurentide Ice Sheet advanced into the midlatitudes (Balco and Rovey, 2010); together with the subsequent, strongly pronounced glacials MIS 98 and 96 (e.g. Lisiecki and Raymo 2005; Bolton et al. 2010; BrighamGrette et al. 2013), it represents the first of a series of early Pleistocene glaciations, ultimately resulting in the glacial/ interglacial cycles that have dominated the Earth's climate throughout the Quaternary (Lisiecki and Raymo 2005; Bartoli et al. 2006; De Schepper et al. 2014).

Despite the decades-old search for the cause underlying the iNHG, the mechanisms involved in this process are still a matter of debate. A number of studies have highlighted the role of the Isthmus of Panama in setting the stage for iNHG, thereby invoking an impact of tectonics on ocean circulation (e.g. Keigwin 1982; Driscoll and Haug 1998; Haug and Tiedemann 1998). Specifically, a shallowing of the Panama Seaway may have strengthened the Gulf Stream and introduced warm, saline waters to the northern North Atlantic, thereby enhancing moisture transport to the northern high latitudes as a necessary precondition for ice-sheet growth. This process may also have increased the freshwater input to the Arctic via Siberian rivers, which via sea-ice formation would have increased the albedo and isolated the high heat capacity of the ocean from the atmosphere. Ice-sheet growth would then have been triggered by changes in obliquity forcing (Driscoll and Haug 1998; Haug and Tiedemann 1998). However, model results indicate that the processes surrounding the closure of the Panama Seaway failed to provide a priming mechanism that promoted glacial inception under favourable orbital conditions; focusing on the glaciation of Greenland, they instead suggest that a reduction in $p \mathrm{CO}_{2}$ drove a significant increase in ice-sheet size (DeConto et al. 2008; Lunt et al. 2008).

Another explanation for the iNHG revolves around palaeoceanographic changes in the North Pacific, notably a reorganisation in upper-ocean conditions at $\sim 2.7 \mathrm{Ma}$ (Haug et al. 1999, 2005). It invokes a pronounced increase in ocean stratification that reduced the exchange between the surface mixed layer and deeper waters. As a consequence of this partial decoupling, the seasonal variation of the surfacewater temperatures increased, with surface-water warming in late summer and fall providing the moisture that enabled icesheet growth in downwind North America.

A promising avenue for testing this hypothesis is the evaluation of Plio/Pleistocene palaeoclimate archives from western North America. The prevalence of westerly winds in the mid-latitudes, their downwind position with respect to the North Pacific Ocean and upwind position relative to the regions of ice-sheet growth in North America make such archives excellent recorders of climatic changes on the North American continent as they may have resulted from a palaeoceanographical reorganisation in the North Pacific. Such an archive has recently become available through sediment drillcores from paleo-Lake Idaho (Idaho, northwestern United States; Fig. 1) that have been retrieved under the auspices of the International Continental Drilling Program (ICDP; Shervais et al. 2006, 2013). Taking advantage of this opportunity, we here present a palynological record from paleo-Lake Idaho that allows us to reconstruct vegetation dynamics and, by extension, climatic changes in northwestern North America during the late Pliocene and early Pleistocene. Augmented by new magnetostratigraphic data that allow age constraints for the drillcore material and quantitative pollenbased climate estimates that provide a measure for the magnitude of climate variability, we further use our datasets in order to critically assess the hypothesis that the subarctic Pacific Ocean served as a source of enhanced moisture for the North American continent from $\sim 2.7$ Ma onwards, thereby setting the stage for major Northern Hemisphere glaciation.

\section{Study area}

Geological setting and evolution of paleo-Lake Idaho

Paleo-Lake Idaho formed during the late Miocene, 9.5 Ma ago, in the western Snake River Plain of Idaho as a result of faultinginduced subsidence in the wake of the eastward-migrating Yellowstone hotspot (Malde and Powers 1962; Pierce et al. 1992; Shervais et al. 2006) and ceased to exist in the early Pleistocene at $\sim 2 \mathrm{Ma}$ (Malde and Powers 1962; Wood and Clemens 2002). Altogether, up to 3-km-thick lacustrine sediments and intercalated volcanics were deposited during that time (McCurry et al. 1997; Wood and Clemens 2002). To date, age control for the evolution of paleo-Lake Idaho is primarily based on radiometric dating of volcanics from the northwestern margin of the western Snake River Plain and palaeomagnetic investigations on outcrop sections in the southern part of the area (Neville et al. 1979); it is further supported by palaeontological data (Othberg 1994, Perkins et al. 1998, Smith et al. 2000). A detailed description of the evolution of paleo-Lake Idaho is provided in the following. 


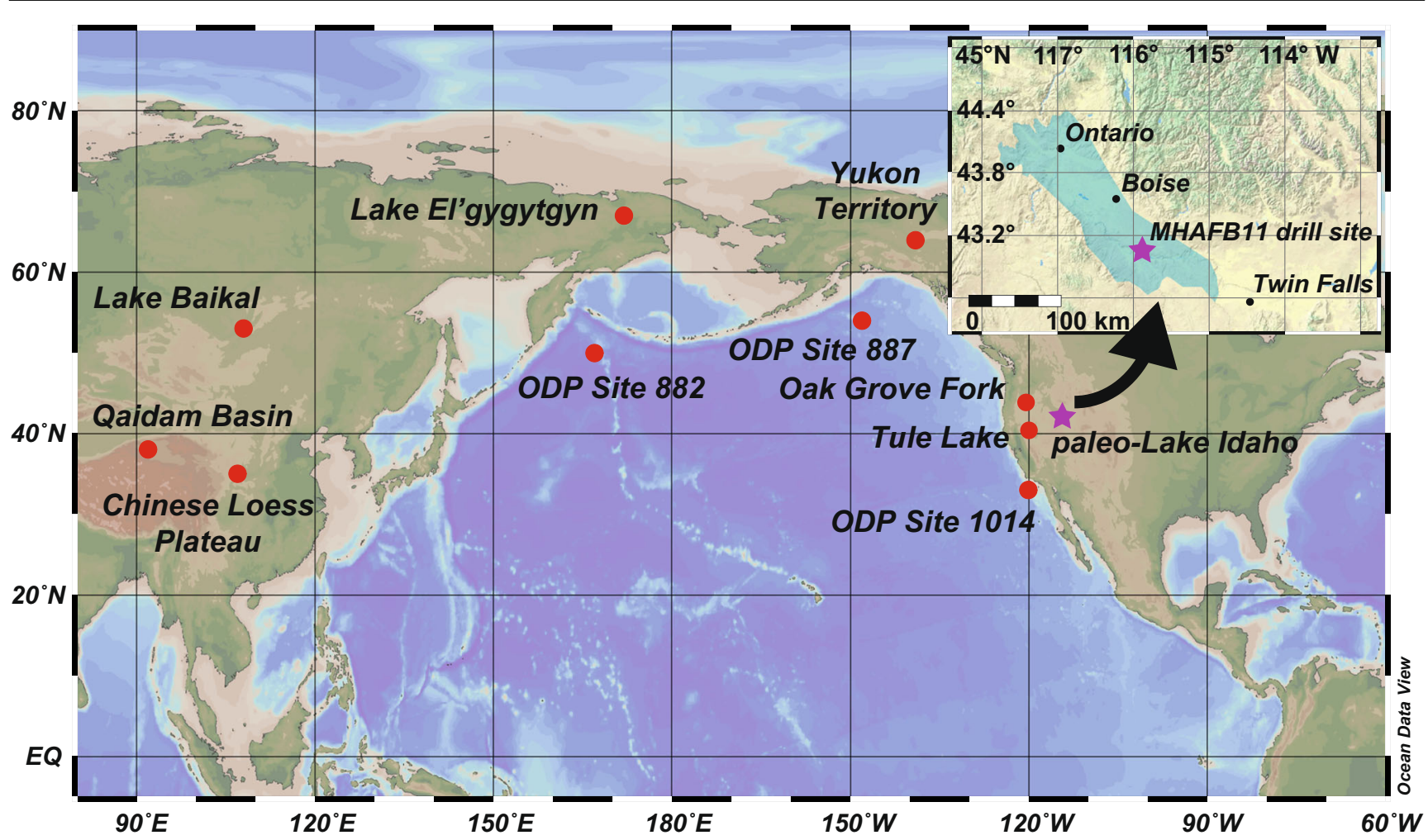

Fig. 1 Overview map showing the locations of terrestrial and marine Plio/Pleistocene records discussed in this study. Inset: Detailed map of the western Snake River Plain with the locality of the MHAFB11 drill site

(purple asterisk). The turquoise area indicates the extent of the western Snake River Plain, which approximates the maximum extent of paleoLake Idaho during the early Pliocene

Following the effusion of basaltic lavas that took place coeval with graben formation, clastic sediments of the Chalk Hills Formation (Fm) were deposited in a shallow lacustrine setting in the western Snake River Plain (Malde and Powers 1962), thus marking the earliest phase in the evolution of paleo-Lake Idaho. Age control for the Chalk Hills Fm comes from $\mathrm{K} /$ Ar dating of a basalt in the lower part of the formation (8.2 \pm 0.7 and 8.6 $\pm 0.5 \mathrm{Ma}$; Armstrong et al. 1975), fissiontrack ages from intercalated ash layers (6.1-9.1 Ma; Kimmel 1982 ) and correlations of intercalated ash layers with previously dated regional ash falls $(6.3 \pm 0.3$ and $6.5 \pm 0.1 \mathrm{Ma}$; Morgan 1992; Perkins et al. 1998).

Separated from the Chalk Hills Fm by an unconformity that resulted from a transient lake-level fall (Kimmel 1982), the Terteling Springs Fm (initially treated as the basal part of the overlying Glenns Ferry Fm; Malde and Powers 1962) was deposited. It consists predominantly of sandstones that were deposited in a lacustrine setting from $\sim 6 \mathrm{Ma}$ onwards (Malde and Powers 1962, Wood and Clemens 2002). Deposition space of the Terteling Springs Fm increased over time, indicating a transgressive phase of paleo-Lake Idaho. This transgression came to a halt in the early Pliocene when the lake level reached a spillover point at the northwestern margin of the basin (Repenning et al. 1994; Van Tassell et al. 2001).
The Terteling Springs Fm is overlain by the Glenns Ferry Fm, which consists predominantly of silt- and claystones (Ekren et al. 1981; Wood and Clemens 2002) that were deposited under relatively quiet hydrodynamic conditions at water depths of up to $\sim 350 \mathrm{~m}$ (Wood and Clemens 2002). Based on magnetostratigraphic data from outcrops in the western Snake River Plain (Neville et al. 1979), the deposition of the Glenns Ferry Fm started before the beginning of the Cochiti Subchron (4.30 Ma after Ogg 2012) and continued across the Gauss/Matuyama polarity reversal (2.59 Ma after Ogg 2012). New magnetostratigraphic information from drillcore material from the western Snake River Plain also documents that the Gauss/Matuyama reversal is positioned within the Glenns Ferry Fm (Allstädt et al. 2020).

Between 3.8 and $2 \mathrm{Ma}$ ago, paleo-Lake Idaho connected to the Columbia River drainage system. Downcutting of the outlet caused a slow draining of the lake (Smith et al. 2000; Van Tassell et al. 2001; Wood and Clemens 2002), and coarsegrained clastics of the "Tuana Gravel" and "Tenmile Gravel" were deposited predominantly along the margins of the basin (Othberg 1994; Wood 1994; Sadler and Link 1996).

In parts of the western Snake River Plain, the Glenns Ferry Fm is overlain by sediments of the Bruneau Fm. Consisting mainly of silt- and sandstones with thin intercalated basalt flows, the Bruneau Fm represents lacustrine deposits that 
formed in relic lakes scattered over the western Snake River Plain (Malde and Powers 1962; Malde 1991). Age constraints for the Bruneau Fm come from radiometric dates and palaeomagnetic information. Its deposition began after the Gauss/Matuyama reversal (Neville et al. 1979) and was terminated between $\sim 2.2$ and $\sim 1.8 \mathrm{Ma}$ as indicated by extensive basalt flows that cap the underlying lacustrine deposits (Shervais and Vetter 2009), thereby marking the end of paleo-Lake Idaho. Fluvial deposits of the middle to late Pleistocene "Black Mesa Gravel" locally overly the Bruneau Fm (Malde and Powers 1962). They are, in turn, overlain by basalts that are as young as $200 \mathrm{ka}$ in parts of the western Snake River Plain (Shervais et al. 2005).

To date, the western Snake River Plain is characterised by a (sub-)tropical steppe climate following the classification of Köppen (1900), with a mean annual temperature of $11.1^{\circ} \mathrm{C}$ and a mean annual precipitation of $179 \mathrm{~mm}$ per year. The region is characterised by strong temperature seasonality with warm summers (mean July temperature: $24.1^{\circ} \mathrm{C}$ ) and cold winters (mean January temperature: $-1.2{ }^{\circ} \mathrm{C}$ ). Precipitation is low throughout the year, with mean values of 5 and $18 \mathrm{~mm}$ in July and January, respectively, during the period between 1918 and 2020 (Canty et al. 2020).

The modern vegetation of the western Snake River Plain is characterised by a semiarid steppe biome consisting of herbs and shrubs with high abundances of Amaranthaceae and Artemisia (Anderson and Holte 1981; Bright and Davis 1982). Arboreal vegetation is largely limited to the mountainous areas north and south of the western Snake River Plain, predominantly consisting of Juniperus and Pinus (Thompson 1996). Occurrences of Pseudotsuga and Abies are restricted to higher elevations in the surrounding mountains that receive higher precipitation (Thompson 1996). Riparian taxa such as Elaeagnus, Populus, Salix and Tamarix are confined to areas in close vicinity to the Snake River (Dixon and Johnson 1999).

\section{Paleo-Lake Idaho as a palaeoclimate archive}

Drilling at paleo-Lake Idaho was conducted within the framework of the HOTSPOT drilling campaign in the western Snake River Plain (Shervais et al. 2006, 2013). The primary goal of the HOTSPOT project was to reconstruct the volcanic, tectonic and geothermal evolution of the Snake River volcanic province in response to the region's migration across the Yellowstone-Snake River hotspot. HOTSPOT drilling took place from 2010 until 2012 and yielded more than $5.9 \mathrm{~km}$ of core from three sites. At the westernmost site (Fig. 1), a series of basalts overlain by a 635 -m-thick succession of mostly fine-grained lacustrine sediments with thin intercalated basalt layers was recovered (Shervais et al. 2013). This new drillcore (termed MHAFB11 due to its location at the Mountain Home Air Force Base and the year of drilling operations) was collected to recover the first complete, high-sedimentation-rate continental palaeoclimate archive for the late Pliocene and early Pleistocene of North America.

Drilling operations at the MHAFB11 site were carried out at $43^{\circ} 070066^{\prime} \mathrm{N}, 115^{\circ} 894339^{\prime} \mathrm{W}$ at an elevation of $920 \mathrm{~m}$ a.s.l. (Fig. 1). They reached a depth of $1821 \mathrm{~m}$, with a core recovery of $>98 \%$. Lithologically, the drillcores consist of an upper basalt unit (0-215 m) capping lacustrine clay-, silt- and sandstones that reach until $735 \mathrm{~m}$ and are underlain by a $26-\mathrm{m}$-thick basalt layer (735-761 m). Further downcore, this basalt is followed by mudstones $(761-850 \mathrm{~m})$. Between $850 \mathrm{~m}$ and $1250 \mathrm{~m}, \geq 50 \mathrm{~m}$ thick basalt layers alternate with sandstones, gravels and volcanic ash. Finally, the 1250-1821-m interval of the MHAFB11 core comprises a series of basalt flows, basaltic sandstones and hyaloclastites (Shervais et al. 2013).

\section{Material and methods}

Age control

The age control of core MHAFB11 is based on palaeomagnetic data, namely (i) the position of the Gauss/Matuyama boundary (2.59 Ma; Ogg 2012), (ii) the fact that the 568-440-m core interval shows reverse polarity and thus pre-dates the Olduvai Subchron and (iii) the position of the upper boundary of the Kaena Subchron (3.03 Ma; Ogg 2012) at $~ 887 \mathrm{~m}$ (Supplementary Fig. 1). The results of the 732-440-m core interval (including the position of the Gauss/Matuyama boundary at $568-\mathrm{m}$ core depth and the polarity of the 568-440-m core interval) have been adopted from Allstädt et al. (2020).

For the present paper, additional palaeomagnetic analyses were carried out on the 958-732 m interval of core MHAFB11 following the laboratory protocols as applied by Allstädt et al. (2020). Specifically, 87 oriented samples (volume: $8 \mathrm{~cm}^{3}$ ) were taken. The samples were either cut from the core segments with a brass blade and subsequently reduced to cubes or drilled as oriented plugs from the core segments. The vertical sampling distances varied between $\sim 2$ and $\sim 3 \mathrm{~m}$. The remanent magnetisation of all samples was measured with a 2$\mathrm{G}$ Enterprises pulse tube direct-current superconducting quantum interference device (DC-SQUID) magnetometer. For thermal demagnetisation ( $\mathrm{ThD})$, specimens were heated in an ASC Model TD48-SC shielded furnace in 14 steps to $600-680{ }^{\circ} \mathrm{C}$ in intervals of $20-80{ }^{\circ} \mathrm{C}$. The acquired dataset was analysed using the software "Remasoft" (Chadima and Hrouda 2006). In order to determine characteristic remanent magnetisation (ChRM) directions, standard techniques have been applied following Kirschvink (1980). All samples yielding a residual intensity $>10 \%$ of the initial value and/or magnetic components with maximum angular deviations (MAD) $>15^{\circ}$ were rejected. In total, 61 out of the 87 samples from the 958-732 $\mathrm{m}$ interval met the selection criteria and were used in the interpretation. The determined polarity sequence resulted 
in the identification of the upper boundary of the Kaena Subchron at $\sim 887 \mathrm{~m}$.

Lithologically, the MHAFB11 core consists largely of fine clastic sediments (i.e. mudstone, siltstone and muddy sands) throughout the interval from $\sim 850 \mathrm{~m}$ (close to where the upper boundary of the Kaena Subchron has been identified) to $440 \mathrm{~m}$ (which delineates the upper boundary of the interval investigated palynologically in our study) (Shervais et al. 2013). In the absence of additional age-control points, the sedimentation rate calculated between the positions of the two identified reversals was tentatively extrapolated linearly across the entire core interval studied. Based on this first-order approximation, our palynological record spans the late Pliocene to early Pleistocene from $\sim 2.8$ to $\sim 2.4 \mathrm{Ma}$. Clearly, the uncertainties involved in this age model increase with the distance from the age-control points used; they are smallest for the core intervals around the age-control points such as the Gauss/Matuyama boundary as they are the focus of our study.

\section{Palynology}

A total of 127 samples were analysed at $\sim 2.3$-m resolution for the core interval from 733 to $440 \mathrm{~m}$. Based on the available age control (compare "Age control"), this core interval spans from $\sim 2.8$ to $\sim 2.4 \mathrm{Ma}$, and the temporal resolution of the palynological dataset is $\sim 3 \mathrm{ka}$.

Per sample, c. $15 \mathrm{~g}$ of sediment were processed following standard palynological techniques as described by Koutsodendris et al. (2019b), including spiking with Lycopodium clavatum marker spores (Lund university, Batch No. 1031 [20,848 \pm 1546 spores/tablet]), treatment with hydrochloric (10\%) and hydrofluoric (40\%) acids and sieving through a $10-\mu \mathrm{m}$ mesh. The slides were analysed using a Zeiss Axioscope A1 light microscope at $\times 400$ and $\times 630$ magnification. Whenever possible, 250 pollen grains (excluding the pollen of Pinus and aquatic plants as well as spores and algae) were counted per sample. For the calculation of pollen percentages, Pinus pollen was excluded in order to avoid misinterpretations related to the natural overrepresentation of these pollen grains in lake sediments (e.g. Koutsodendris et al. 2019b). Pollen from aquatic plants, spores and algae were also excluded from the main sum. The percentages of these taxa were calculated on the basis of the main sum plus the counts for the individual taxa.

Statistical evaluation

In order to define pollen assemblage zones (PAZ) we applied stratigraphically constrained cluster analysis to the pollen data (Grimm 1987), which groups data by minimizing the withincluster variability dispersion (sum of squares). The optimal number of clusters was determined using the 'broken-stick' model (Bennett 1996). For this step, we utilised the functions 'chclust' and 'bstick' as implemented in the R software package rioja (Juggins 2017). In addition, significant groups were visualised in a dimensionally reduced space using a PCA, which further explores elemental variations in the depth domain. The PCA was performed using the program PAST (Hammer et al. 2001).

To identify potential orbital frequencies in the pollen data we applied spectral analyses to the tree percentages of our record. We combined Multitaper Spectral (MTM; Thomson 1982) and REDFIT analyses (Schulz and Mudelsee 2002) to statistically identify the dominant frequencies and cycles in the depth domain and to assign these cycles to the orbital frequencies of eccentricity, obliquity and precession. MTM analysis requires strictly regular sample steps to be performed; however, this also causes a loss of amplitude in the highfrequency fluctuations due to resampling (Martinez et al. 2016). In contrast, REDFIT calculates the spectrum of unevenly sampled series, which can be biased in the high frequencies due to the non-independency of the frequencies (Schulz and Mudelsee 2002). Both spectra were calculated using the time series functions implemented in the PAST program (Hammer et al. 2001).

Due to the data gap between 624 and $600 \mathrm{~m}$, we have separated our pollen record into two intervals, which helps to reduce the potential of introducing artefacts. Hence, the spectral analyses were carried out on two intervals, i.e. from 733 to $624 \mathrm{~m}$ and from 600 to $440 \mathrm{~m}$. Prior to MTM analysis, the pollen data were resampled at a resolution of $2.09 \mathrm{~m}$ (corresponding to $\sim 2.9 \mathrm{kyr}$ in the time domain according to our age model).

\section{Quantitative palaeoclimate estimates}

Quantitative palaeoclimate estimates based on the nearest living relatives of the sporomorph-producing plants were performed using probability density calculations (e.g. Hyland et al. 2018). The modern-day geographic distributions of the nearest living relatives were extracted from the Global Biodiversity Information Facility (www.gbif.org). To enhance the sensitivity of the selected approach to continental climates similar to those prevailing in the western Snake River Plain today, the nearest-living-relative data were restricted to North America, excluding information from relative maritime settings in Europe. Exceptions were made for modern living relatives that presently do not occur in North America. Additionally, the modern-day distribution data were filtered based on (i) exoticism (with records outside the taxon's native range being excluded) and (ii) spatial overrepresentation (with duplicate records and ambiguous data being removed). The full record was randomly filtered to exclude all but three records in each $0.1^{\circ} \times 0.1^{\circ}$ gridcell and all but ten records in each $1^{\circ} \times 1^{\circ}$ gridcell; this step was carried 
out in order to counterbalance overrepresentation of areas in our probability analysis with more recorded observations. The climatic range of a plant group (Supplementary Table 1) was then determined using the remaining geodetic coordinates of occurrences, and climatic data were extracted from gridded climate data using the 'dismo' package in R (Hijmans et al. 2005).

The approach used here differs from nearest living relative techniques such as the coexistence approach (e.g. Mosbrugger and Utescher 1997; Pross et al. 2000) in two ways: Firstly, we evaluate the distribution of plant groups as the effect of multiple climatic variables together rather than evaluating each climatic variable separately. Second, we employ a probability density function to evaluate the highest probability distribution of the plants in the assemblage rather than employing absolute or percentile-based range cutoffs. The climatic range of a taxon may be underpinned by a combination of climatic factors, a possibility that is overlooked when evaluating climatic variables separately (Grimm and Potts 2016). The probability density approach considers the likelihood $(f)$ of a taxon $(t)$ occurring at a combination of climatic variables. Here, we evaluated the likelihood of a plant taxon occurring at a combination of mean annual temperature (MAT), mean annual precipitation (MAP) and summer and winter precipitation (SP and WP). These combinations represent 50,000 unique potential climatic combinations where temperature and precipitation variables were changed with increments of $0.1{ }^{\circ} \mathrm{C}$ and with $0.1 \log \mathrm{mm}$, respectively. The likelihood of a taxon occurring at a specific combination of climatic variables is then calculated as:

$$
\begin{aligned}
f\left(t_{n}\right)= & \left(\frac{1}{\sqrt{2 \sigma_{M A T^{2} \pi}}} e^{\left(x_{M A T^{-}}-\mu_{M A T}\right)^{2} / 2 \sigma_{M A T}{ }^{2}}\right) \\
& \times\left(\frac{1}{\sqrt{2 \sigma_{M A P^{2} \pi}}} e^{\left(x_{M A P}-\mu_{M A P}\right)^{2} / 2 \sigma_{M A P}{ }^{2}}\right) \\
& \times\left(\frac{1}{\sqrt{2 \sigma_{S P}^{2} \pi}} e^{\left(x_{S P}-\mu_{S P}\right)^{2} / 2 \sigma_{S P}{ }^{2}}\right) \\
& \times\left(\frac{1}{\sqrt{2 \sigma_{W P}^{2} \pi}} e^{\left(x_{W P}-\mu_{W P}\right)^{2} / 2 \sigma_{W P}{ }^{2}}\right)
\end{aligned}
$$

Then, the likelihood of each taxon was combined to create an overall $(z)$ probability representative of each taxon in the assemblage. The taxa in the assemblage represent each sporomorph taxon that can be attributed to a modern plant group, with a 40th percentile threshold from background occurrences. The rationale behind this step is that some plant types such as Pinus occur in all samples, which makes using presence/absence to determine its climatic significance irrelevant. However, by using the 40th percentile threshold abundance, a reduction from high background values in Pinus gets incorporated into the palaeoclimate reconstruction. The likelihood of a group of taxa occurring at a specific combination of climatic variables is then calculated as:

$f(z)=f\left(t_{1}\right) \times f\left(t_{2}\right) \times \ldots \times f\left(t_{n}\right)$

We then assigned $95 \%$ confidence intervals indicative of the climatic combinations under the probability density curve that were $>0.05 \%$ as likely as the highest probability (Willard et al. 2019).

In order to assess the fidelity of our palaeoclimate reconstructions, we carried out sensitivity tests on modern vegetation assemblages from Idaho close to the MHAFB11 site. Two sites were selected, one in the mountainous Stack Rock area north of Boise and one in the Snake River Plain south of Boise. Bounding boxes were created for both sites: $43.7^{\circ} \pm$ $0.05^{\circ} \mathrm{N},-116.1^{\circ} \pm 0.05^{\circ} \mathrm{E}$ for the Stack Rock site and $43.25^{\circ} \pm 0.05^{\circ} \mathrm{N},-116.35^{\circ} \pm 0.05^{\circ} \mathrm{E}$ for the Snake River Plain site. All plant species recorded within these bounding boxes in the Global Biodiversity Information Facility were used in the sensitivity test (Supplementary Table 2). In order to ensure that the taxonomic constraints in the sensitivity test and in the palaeoclimate analysis were similar, we carried out ten simulations with 15-20 taxa that were random subsets of the genera or families of the species recorded in the bounding box (Supplementary Table 2). The resulting groups of genera and families were analysed following the same approach as used for the nearest living relative analyses and described above. The resulting climate estimates were then compared with actual climate from the sites, which were based on averaged conditions within the bounding boxes (Supplementary Table 2) after Fick and Hijmans (2017).

\section{Results}

Palynology of the MHAFB11 core

Of the 127 samples analysed from the 733-440-m interval of the MHAFB11 core, 110 yielded highly diverse, wellpreserved pollen and spore assemblages (Supplementary Table 1). In total, 97 different pollen taxa have been identified. The mean counting sum is 258 grains per sample (range: $202-$ 333 grains). For 17 samples between 548 and 519 m, only low counting sums were achieved due to the very low sporomorph concentration in the sediment (mean counting sum: 33; range: 4-157). Whereas the average pollen concentration is $\sim 2500$ specimens per gram of dry sediment for the highly productive samples, it is only $\sim 19$ specimens per gram of dry sediment in the 548-519-m depth interval.

Three pollen assemblage zones (PAZ) were defined, with PAZ A comprising the late Pliocene part of the record (733$624 \mathrm{~m}$; c. 2.8-2.7 Ma), PAZ B spanning across the Plio/ 
Pleistocene transition (600-506 m; c. 2.6-2.5 Ma) and PAZ C comprising the early Pleistocene part of the record (504$440 \mathrm{~m} ; 2.5-2.4 \mathrm{Ma}$ ) (Fig. 2). The composition of the palynofloras in the individual pollen zones is briefly described in the following.

\section{PAZ A (733-624 m; c. 2.8-2.7 Ma)}

The lowermost part of the record is characterised by high abundances of pollen from conifer taxa (mean 53.7\%, maximum 75.4\%). Picea (mean 37.2\%) and Pinus (mean 60.8\%) are the dominant coniferous taxa; Abies and Juniperus/ Taxodium are continuously present in PAZ A, whereas Taxus and Tsuga occur only sporadically (Fig. 2). The percentages of deciduous trees (e.g. Juglans, Quercus and Fraxinus) are low throughout this zone (mean $2.6 \%$, max $11.6 \%)$. The dominant non-arboreal components in PAZ A (mean 42.9\%) are Cyperaceae (12.9\%), Asteraceae (10.4\%), Artemisia (9.9\%) and Poaceae (3.8\%).

Our quantitative pollen-based climate estimates indicate average values of $\sim 9^{\circ} \mathrm{C}$ for MAT in PAZ A. Average values for precipitation-related parameters are $\sim 830 \mathrm{~mm} / \mathrm{a}$ for MAP, $\sim 230 \mathrm{~mm} / \mathrm{a}$ for SP and $\sim 170 \mathrm{~mm} / \mathrm{a}$ for WP (Fig. 3).

PAZ B (600-506 m; c. 2.6-2.5 Ma)

The lowermost part of PAZ B (i.e. $600-570 \mathrm{~m}$ ) is characterised by a drop in the percentages of conifer taxa from $\sim 40$ to $18 \%$; subsequently, conifer percentages increase to $42 \%$ between 569 and $550 \mathrm{~m}$ before decreasing again towards the top of the zone at $506 \mathrm{~m}$ to $14 \%$ (Fig. 2). Whereas the percentages of Picea, Pinus and Abies exhibit marked fluctuations, Juniperus/Taxodium percentages remain nearly stable throughout this zone. Above $\sim 535 \mathrm{~m}$, abrupt increases of Taxus (max $3.1 \%)$ and Tsuga $(\max 18.2 \%)$ are recorded. Opposite trends emerge for the percentages of deciduous trees: they remain stable between 600 and $570 \mathrm{~m}$, where they reach a mean value of $2.1 \%$, before they increase slightly between 569 and $550 \mathrm{~m}$ to up to $10 \%$, and ultimately reach substantially higher values (mean 29.3\%) in the upper part of the zone between $\sim 550$ and $506 \mathrm{~m}$ (Fig. 2). The most dominant deciduous tree taxa in PAZ B are Juglans and Quercus, with several other taxa occurring sporadically such as Betula, Sorbus, Ulmus, Fraxinus, Alnus and Corylus (Fig. 2). Compared with PAZ A, PAZ B shows slightly higher percentages of non-arboreal pollen taxa (mean $61.9 \%$ ), which is largely due to increased percentages of Cyperaceae and Poaceae. Markedly, Amaranthaceae percentages increase from 1.5 to $10.8 \%$ at the expense of Artemisia percentages (from 8.3 to $0.9 \%$ ) across PAZ B.

The pollen-based quantitative climate estimates suggest a gradual increase in MAT (from 9 to $10^{\circ} \mathrm{C}$ ), MAP (from 790 to $890 \mathrm{~mm} / \mathrm{a}$ ), SP (from 220 to $250 \mathrm{~mm} / \mathrm{a}$ ) and WP (from 160 to
$190 \mathrm{~mm} / \mathrm{a}$ ) throughout PAZ B (Fig. 3). The mean precipitation-related parameters in PAZ B are $\sim 850 \mathrm{~mm} / \mathrm{a}$ for MAP, $\sim 240 \mathrm{~mm} / \mathrm{a}$ for SP and $\sim 170 \mathrm{~mm} / \mathrm{a}$ for WP, indicating an increase in mean MAP and SP in comparison with PAZ A, whereas WP remained stable.

\section{PAZ C (504-440 m; c. 2.5-2.4 Ma)}

In PAZ C, the percentages of conifer taxa are the lowest of our entire pollen record. Whereas the percentages of Picea, Pinus and Juniperus/Taxodium show a pronounced variability (Fig. 2), Abies percentages remain relatively stable throughout this zone (mean: $2.8 \%$ ). Taxus occurs sporadically (max $3.1 \%$ ). The percentages of deciduous tree pollen are lower (mean: $7 \%$ ) than in the upper part of PAZ B (mean 14.6\%), but higher than in PAZ A (mean 2.6\%). In contrast to PAZs B and A, deciduous tree taxa are constantly present throughout the zone, including Juglans (mean 1.8\%), Quercus (3.9\%), Sorbus (0.9\%), Ulmus $(0.6 \%)$ and, to a lesser extent, Betula (0.4\%) and Fraxinus (0.5\%) (Fig. 2).

Non-arboreal taxa reach their maximum percentages (mean: 65.4\%) of the entire record in PAZ C, with the dominant taxa being Amaranthaceae (8.7\%), Cyperaceae (22.8\%), Asteraceae (11.8\%) and Poaceae (13.8\%). In addition, the aquatic taxon Sparganium is continuously present in PAZ C, albeit in low abundances (max 2.0\%) (Fig. 2).

The quantitative climate estimates for PAZ C are similar to those from the upper part of PAZ B with respect to both temperature and precipitation-related parameters. Mean values are $9{ }^{\circ} \mathrm{C}$ for MAT. Mean values for precipitation parameters are $850 \mathrm{~mm} / \mathrm{a}$ for MAP, $240 \mathrm{~mm} / \mathrm{a}$ for $\mathrm{SP}$ and $170 \mathrm{~mm} / \mathrm{a}$ for WP (Fig. 3).

\section{Principal component analysis}

Principal component analysis of the pollen dataset yielded three major components that together explain $69.8 \%$ of the total variance (Table 1). The first component (PC1) accounts for $47.8 \%$ of the total variance and is bipolar. It is marked by the positive loadings of Abies, Picea and Pinus, and the negative loadings of Amaranthaceae and Poaceae (Table 2, Fig. 4). The second component (PC2) explains $13.5 \%$ of the total variance and is also bipolar. The positive pole of PC2 is marked by high loadings of Pinus, Juniperus/Taxodium, Cyperaceae, Poaceae and Asteraceae (Senecio type); the negative pole is primarily driven by high loadings of Picea, Betula and Sorbus type (Table 2, Fig. 4). The third component (PC3) accounts for $8.5 \%$ of the total variance and is also bipolar (Supplementary Fig. 2). It is characterised by the positive loadings of Juniperus/Taxodium and Artemisia and the negative loadings of Poaceae, Cyperaceae and, to a lesser extent, Picea (Table 2). 


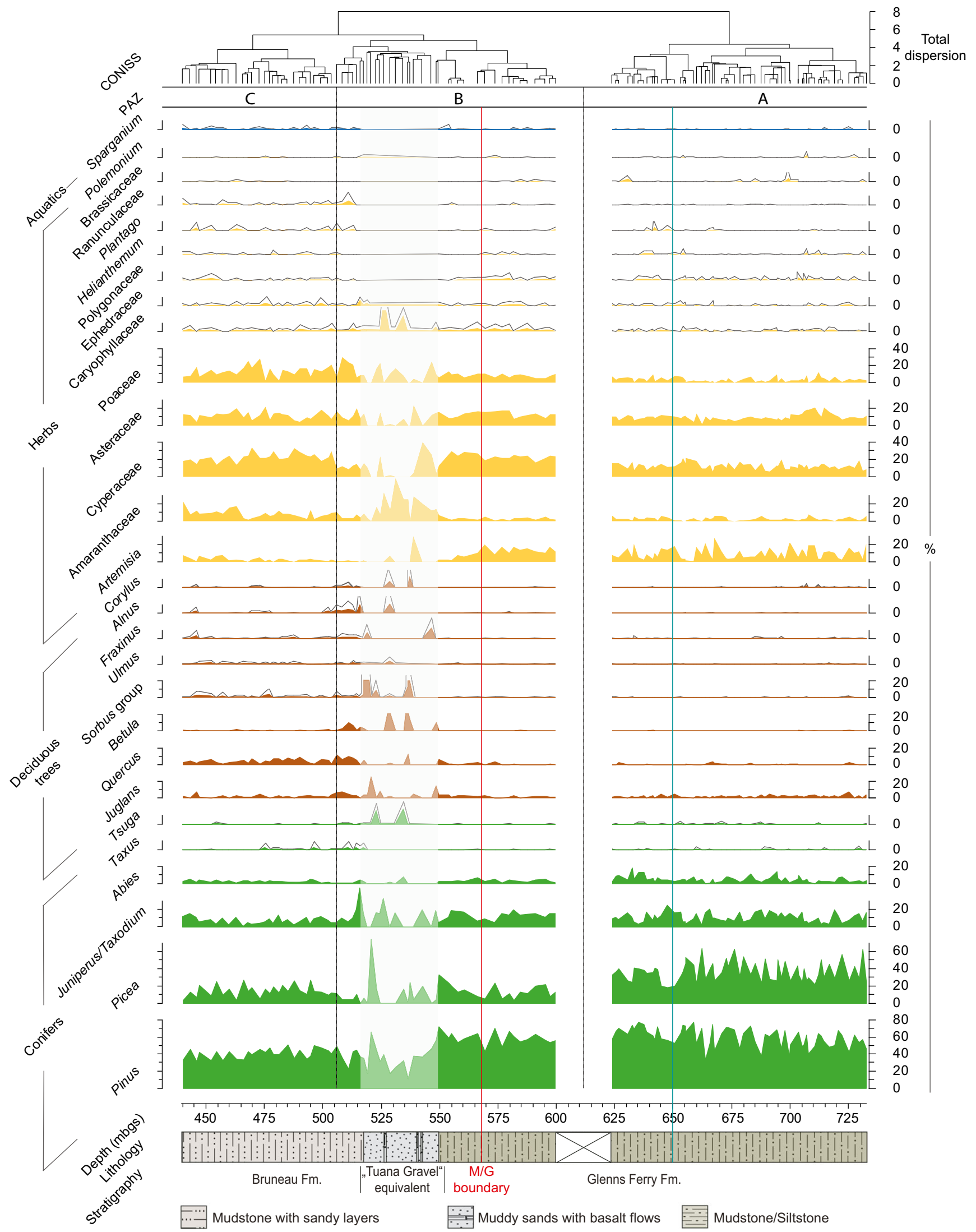


Fig. 2 Selected pollen taxa (conifer taxa in green, deciduous tree taxa in brown, herb taxa in yellow, and aquatic taxa in blue) as identified in the 733-440 m interval of the MHAFB11 core. Pinus pollen has been excluded in the calculation of pollen percentages. The vertical red line marks the Gauss/Matuyama boundary as identified by Allstädt et al. (2020). The vertical blue line marks the core depth of the lake-level lowering that is potentially related to the connection of paleo-Lake Idaho with the Columbia River drainage system. Interval with muted colours (548-519 m) marks the part of the succession that has yielded low pollen concentrations

\section{Discussion}

Long-term vegetation development at paleo-Lake Idaho

\section{Vegetation change across the Plio/Pleistocene transition}

The palynological data from core MHAFB11 document that forests have dominated the catchment of paleo-Lake Idaho throughout the studied time interval from $\sim 2.8$ to $\sim 2.4$ Ma. Despite the dominance of forest vegetation, herbaceous plants increased their presence over the course of the study interval (Fig. 2). Importantly, the forest biome changed markedly across the Plio/Pleistocene transition: The conifer-dominated forests of the late Pliocene were replaced by open mixed conifer/deciduous forests in the early Pleistocene (Figs. 2, 3). This shift in forest composition, which occurred at 2.6 Ma based on the available age control, is clearly reflected by our PCA results. Specifically, the first component (PC1), which differentiates the positive loadings of Picea, Pinus and Abies from the negative loadings of Amaranthaceae, Poaceae, Betula and Sorbus (Table 2), is interpreted to represent the differentiation between conifer and open mixed forests. Perhaps even more interestingly, the downcore PC1 scores show a shift from positive to negative values at $\sim 2.6 \mathrm{Ma}$, which indicates a shift in forest dynamics in the catchment area of paleo-Lake Idaho and, by extension, in western North America.

Our findings on a Plio/Pleistocene vegetation turnover are consistent with those from a previous palynological study from the close vicinity of the MHAFB11 site (Thompson 1996). Although being of lower resolution than our dataset, this study indicates a gradual transition from high abundances of conifer taxa in the Pliocene to an increasingly open environment with higher abundances of steppe taxa in the Pleistocene. On a larger scale, our findings of a coniferdominated environment during the late Pliocene are corroborated by palynological data from Oregon and California (Thompson 1991), and also from the Yukon Territory (Pound et al. 2015) (Fig. 1). Despite their low number, the available records suggest in unison that conifer forests were dominant across large parts of western North America during the late Pliocene. They were replaced by more open mixed conifer/deciduous forests during the earliest Pleistocene. In highly continental settings further towards the centre of the North American landmass, such as around the Great Salt Lake (Utah), Pinus- and Artemisia-dominated biomes of the Pliocene were replaced by an even more open vegetation in the early Pleistocene (Davis and Moutoux 1998). These findings gain further support by model-based biome reconstructions for the late Pliocene that suggest open conifer woodlands and temperate xerophytic shrublands in western North America (Salzmann et al. 2013). According to these reconstructions, the fluctuations between open conifer woodlands and temperate shrublands occurred in dependence of the prevailing climatic conditions, notably between colder/drier and warmer/wetter intervals of the late Pliocene in western North America. In light of these findings, the major vegetation shift at the Plio/Pleistocene boundary in the Snake River Plain as indicated by our dataset and the record of Thompson (1996) must have been caused by climatic forcing, particularly a shift to wetter conditions as indicated by our quantitative precipitation estimates (compare "Forcing factors for vegetation change").

Besides documenting a shift in forest composition at the Plio/Pleistocene boundary, our pollen data also suggest a lakelevel decline of paleo-Lake Idaho at $\sim 2.7 \mathrm{Ma}$ based on our age model, which precedes the observed shift in forest composition at $\sim 2.6 \mathrm{Ma}$. Importantly, the former event occurred stratigraphically earlier (i.e. lower) in the MHAFB11 core than the latter, which allows to firmly exclude potential limitations of our age model as the reason for the observed temporal offset. Increasing percentages of Poaceae and Cyperaceae at $\sim 2.7 \mathrm{Ma}$ (Fig. 2) suggest an expansion of marshlands, and the coeval increase of aquatic-plant percentages points towards an expansion of the littoral zone. Moreover, the PCA results for our palynological dataset show a shift in the scores of PC2 and PC 3 from negative to positive and from positive to negative values, respectively, at $\sim 2.7 \mathrm{Ma}$ (Supplementary Fig. 3). PC2 and PC3 differentiate between taxa that are more common on dry soils (e.g. Pinus, Artemisia and Juniperus) in the surroundings of paleo-Lake Idaho from taxa typically growing on wet soils (e.g. Picea, Betula and Sorbus) and marshes (e.g. Cyperaceae and Poaceae) (Table 2). As such, the observed shifts in the scores of PC2 and PC3 indicate a soil-moisture reduction in the catchment area of the lake and an expansion of marsh conditions towards the depocentre of the basin. These palynological observations consistently indicate a pronounced lake-level decline of paleoLake Idaho at $\sim 2.7$ Ma during deposition of the Glenns Ferry Fm. Previous studies highlight that the connection of paleoLake Idaho to the draining system of the Columbia River occurred during times of the deposition of the Glenns Ferry Fm (Repenning et al. 1994; Wood and Clemens 2002). This may indicate that the here observed lake-level drop at $2.7 \mathrm{Ma}$ marks the timing of this geomorphological process. Independent support for lake-level lowering during the Plio/ 


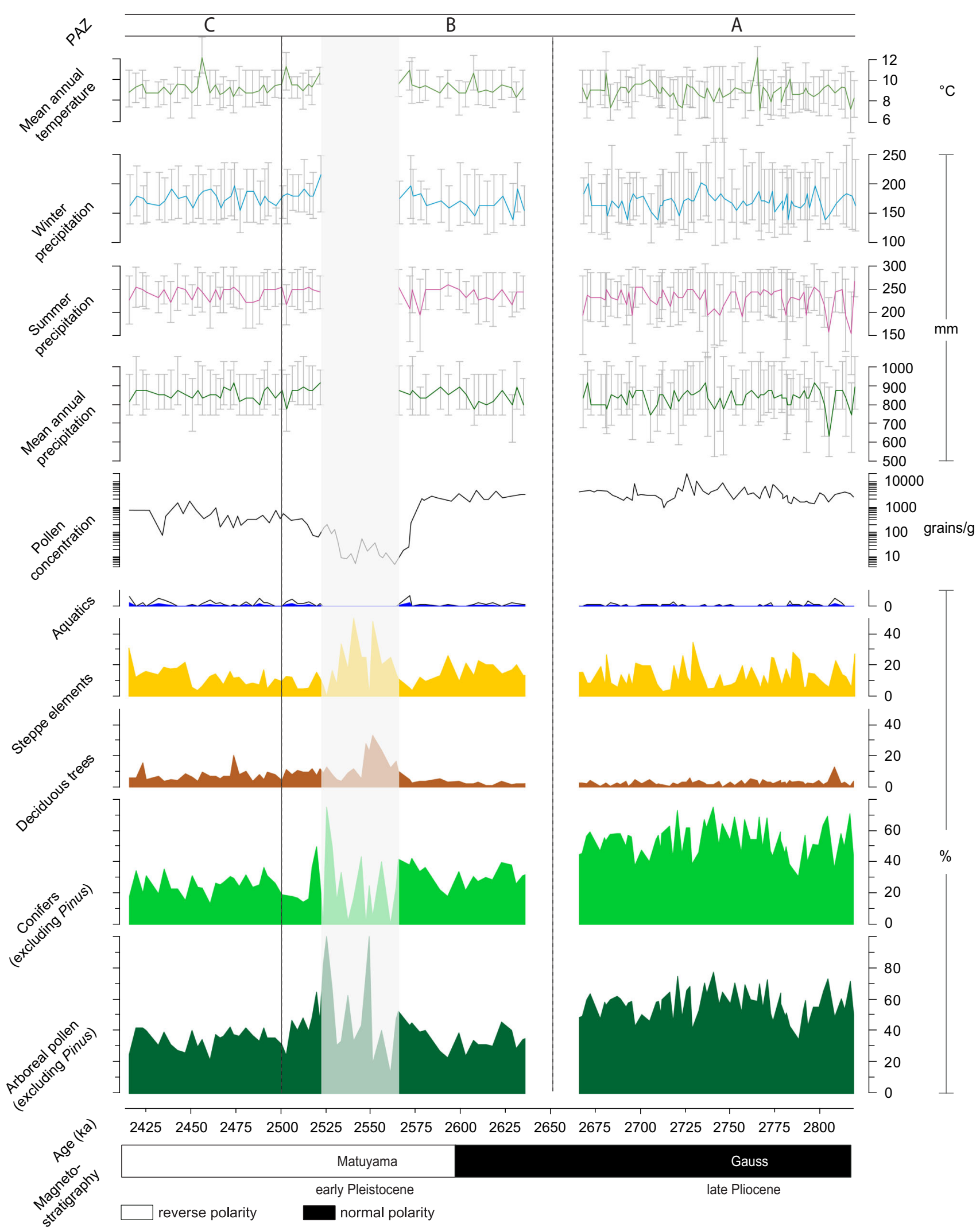

Pleistocene comes from seismic data for the western Snake River Plain (Wood 1994). They reveal progradational prodelta deposits and unconformities across parts of paleo-Lake Idaho.
The progradational prodelta deposits have dips of $2-5^{\circ}$; this rather shallow inclination implies that even small changes in lake level resulted in major horizontal displacements of the 
Fig. 3 Selected pollen groups, pollen concentration and pollen-based quantitative climate estimates of the paleo-Lake Idaho record between $\sim 2.8$ and 2.4 Ma. Conifer taxa comprise Picea, Juniperus/Taxodium, Abies, Taxus, and Tsuga. Deciduous trees comprise Juglans, Quercus, Betula, Sorbus group, Ulmus, Fraxinus, Alnus, and Corylus. Steppe elements comprise Artemisia, Amaranthaceae, and Ephedraceae. Aquatics comprise Alisma, Myriophyllum, Menyanthes trifoliata, Nuphar, Nymphaea, Sparganium, and Typha. Pollen assemblage zones (PAZ) are based on the CONISS dendrogram (Grimm 1987)

shoreline, thereby strongly affecting the littoral zone. Although the timing of these changes in depositional environment is poorly constrained, it appears well possible that they coincided with the palynologically documented lakelevel decline. Combining these lines of evidence, a marked decline in lake level that occurred at $\sim 2.7 \mathrm{Ma}$ appears to be related to headwater erosion at the lake's outlet rather than regional climate.

\section{Forcing factors for vegetation change}

The timing of the shift in the dominant forest biome at 2.6 Ma around paleo-Lake Idaho and at further locations in western North America is consistent with the timing of the iNHG (e.g. Shackleton et al. 1984), which raises the question about potential linkages between both processes. A scenario of climatically induced vegetation change is supported by mid- to highlatitude pollen records in Asia such as from the Qaidam Basin (Koutsodendris et al. 2019a), Lake Baikal (Demske et al. 2002) and Lake El'gygytgyn (Tarasov et al. 2013). These records consistently exhibit vegetation shifts to more open environments that coincide with the onset of cooler and drier conditions in the Northern Hemisphere (e.g. Ruddiman and Kutzbach 1989; Mudelsee and Raymo 2005).

Interestingly, our pollen-based quantitative climate estimates for core MHAFB11 suggest a slight increase in MAT values across the Plio/Pleistocene boundary at paleo-Lake Idaho; moreover, they show increases in MAP, SP and WP trends (Fig. 3). These results are not compatible with an onset of cooler and drier conditions in the Northern Hemisphere during that time. This apparent contradiction may be at least partially resolved when considering the limitations of pollenbased temperature reconstructions for climatically highly dynamic periods such as the Plio/Pleistocene transition. In a climatic regime characterised by alternating glacials and interglacials, the vegetation composition during an interglacial is

Table 1 Total variance explained by the first three PCA components of the pollen dataset from the MHAFB11 core

\begin{tabular}{lll}
\hline PC & Eigenvalue & \% variance \\
\hline 1 & 452.20 & 47.8 \\
2 & 127.68 & 13.5 \\
3 & 80.16 & 8.5 \\
\hline
\end{tabular}

Table 2 PCA loadings of selected pollen taxa from the MHAFB11 core

\begin{tabular}{llll}
\hline & PC1 & PC2 & PC3 \\
\hline Abies & 0.082 & 0.071 & -0.022 \\
Picea & 0.73 & -0.488 & -0.113 \\
Pinus & 0.601 & 0.623 & -0.037 \\
Amaranthaceae & -0.202 & -0.024 & -0.056 \\
Poaceae & -0.183 & 0.25 & -0.454 \\
Juniperus/Taxodium & -0.04 & 0.239 & 0.657 \\
Cyperaceae & -0.042 & 0.356 & -0.337 \\
Senecio type & 0.002 & 0.109 & 0.029 \\
Betula & -0.083 & -0.178 & -0.020 \\
Sorbus type & -0.086 & -0.252 & -0.055 \\
Artemisia & 0.036 & 0.049 & 0.448 \\
\hline
\end{tabular}

strongly influenced by the climate conditions of the preceding glacial and in disequilibrium with the currently prevailing climate (Müller et al. 2003; Herzschuh et al. 2016). A prominent example - although from a higher-latitude setting than paleoLake Idaho - is the vegetation record from Lake El'gygytgyn (northern Siberia; Figs. 1, 5), where quantitative pollen-based temperature estimates do not reflect global temperature and ice-volume trends across the Plio/Pleistocene transition (Herzschuh et al. 2016). Similarly, quantitative temperature estimates derived from the early Pleistocene (2.6-1.7 Ma), mid-latitude pollen record from Lieth (northern Germany) do not mirror the global cooling during that time; instead, they show relatively stable summer temperatures and a high variability in winter temperatures without a trend towards overall colder conditions (Pross and Klotz 2002).

In contrast to the quantitative temperature estimates, our quantitative precipitation estimates yield an unambiguous signal of wetter conditions across the Plio/Pleistocene boundary. Irrespective of our quantitative climate reconstructions, such a trend to higher-humidity conditions is also evidenced by increased percentages of taxa with high moisture requirements during the growing season such as Taxus (Thomas and Polwart 2003) and Tsuga (Gavin and Hu 2006) (Fig. 2).

The precipitation values of $\sim 800 \mathrm{~mm} / \mathrm{a}$ that we have reconstructed for the Plio/Pleistocene transition are remarkably high considering that modern precipitation in the area is only $179 \mathrm{~mm} / \mathrm{a}$ (Canty et al. 2020). As indicated by sensitivity tests applied to modern-day plant assemblages from the western Snake River Plain (compare "Quantitative palaeoclimate estimates" and Supplementary Table 2), this discrepancy can be attributed to a systematic overestimation of the absolute precipitation reconstructions by about $300 \mathrm{~mm} / \mathrm{a}$. However, despite this overestimation of mean annual precipitation for the Plio/Pleistocene, the relative changes in precipitation across the studied time interval still yield a valid signal. Therefore, the observed shift to wetter conditions across the Plio/ 
Fig. 4 Principal component analysis of the palynological dataset from the MHAFB11 core. The first two components explain $61.3 \%$ of the total variance. Only pollen taxa with high loadings (> 0.1 ) in the first three components are labelled

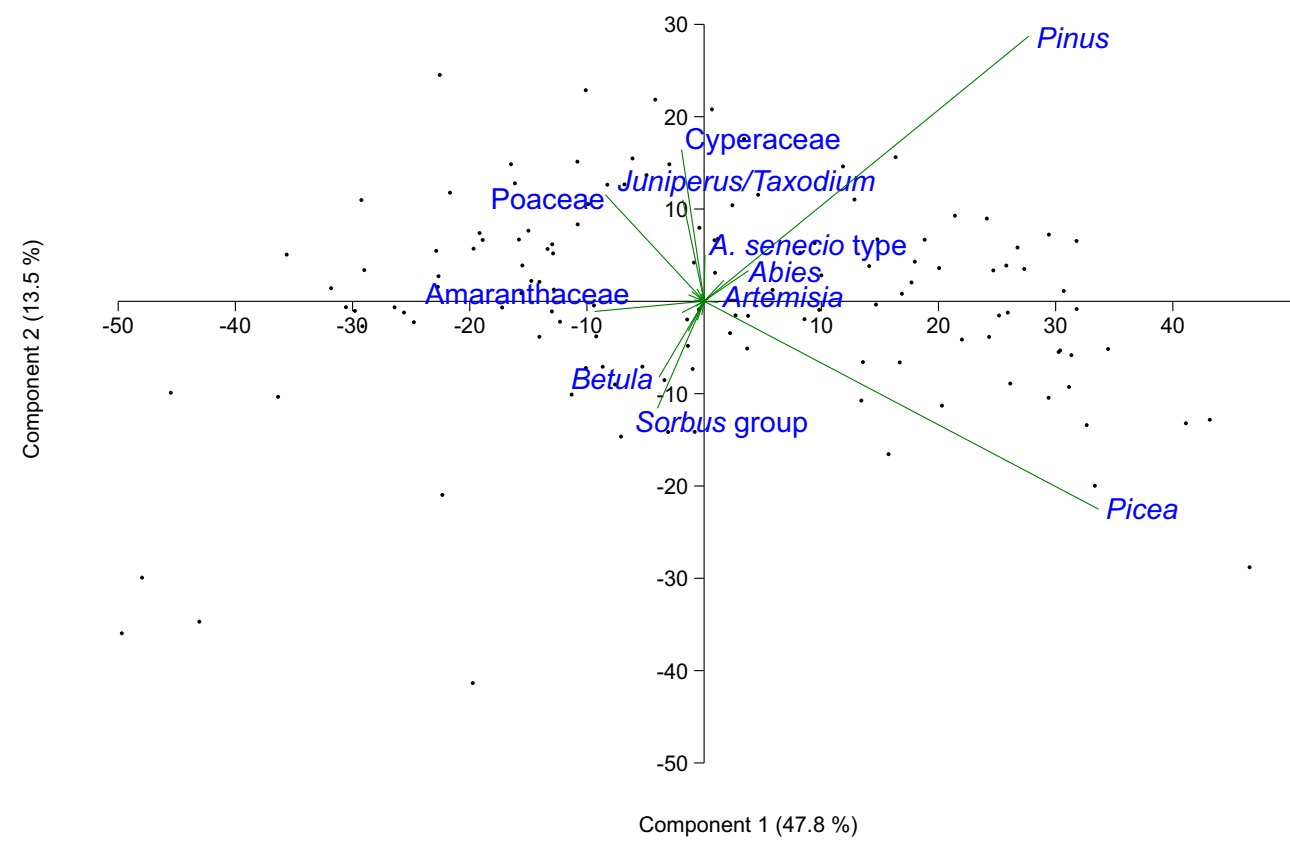

Pleistocene boundary merits special attention. It contradicts the notion of drier terrestrial ecosystems in mid- and high latitudes of the Northern Hemisphere during that time as it has emerged consistently from biotic and abiotic proxy records from Central Asia. There, pollen data from the Qaidam Basin (NE Tibetan Plateau; Fig. 1) show a strong vegetation turnover from an Ephedraceae/Amaranthaceaedominated steppe/semi-desert biome to an Artemisial Amaranthaceae-dominated steppe/semi-desert biome synchronous with early Northern Hemisphere glaciation events during the Pliocene, documenting a shift to drier conditions at that time (Koutsodendris et al. 2019a). This vegetation turnover is coeval with an increase in aeolian deposition on the Chinese Loess Plateau (Fig. 1) that has been attributed to enhanced aridity due to a reorganisation of the East Asian Monsoon (e.g. Ding et al. 1999; An et al. 2001; Sun et al. 2010) (Fig. 5). As already mentioned above, pollen data from Lake Baikal (southern East Siberia; Fig. 1) also indicate a shift to drier conditions at $\sim 2.6 \mathrm{Ma}$ (Demske et al. 2002), and pollen data from Lake El'gygytgyn (northern Siberia) (Figs. 1 and 5) document a transition from cool mixed forests and conifer forests during the Pliocene to tundra biomes during the Pleistocene, suggesting a trend to increasingly dry conditions (Tarasov et al. 2013).

A possible reason for the discrepancy in moisture availability between western North America and Asia during the Plio/ Pleistocene transition involves a palaeoceanographic reorganisation in the Pacific Ocean. At $\sim 2.7 \mathrm{Ma}$, a strong, modern-like halocline developed in the subarctic North Pacific, resulting in a reduced exchange between surface waters and the ocean interior (Haug et al. 2005). This partial decoupling reduced the buffering of surface-water temperature changes via the heat capacity of the deeper water column. Consequently, the seasonal variation of the surface-water temperatures increased, with seasurface warming in late summer and early fall that led to stronger evaporation into the atmosphere (Fig. 5). As the subarctic Pacific is the dominant water vapour source for North America (Bryson 1965; Shinker et al. 2006), this process provided the moisture necessary for the build-up of ice sheets in downwind North America. At the same time, surface-water temperatures during winter and early spring cooled, providing a further important precondition for continental cooling in North America (Haug et al. 1999, 2005).

It appears plausible that this scenario did not only provide the necessary moisture for the development of ice sheets in the high latitudes of North America but can also explain the vegetation shifts documented in the mid-latitude pollen records from paleo-Lake Idaho. However, the palaeoceanographic reorganisation at $\sim 2.7 \mathrm{Ma}$, as indicated by the development of a strong halocline at ODP Site 882 (Haug et al. 2005), clearly precedes the major biome shift at $\sim 2.6 \mathrm{Ma}$ at paleoLake Idaho (Fig. 3). We consider this temporal offset to result from a combination of age-model uncertainties and the response time connected to a possible indirect forcing mechanism. Such an indirect forcing could be related to the build-up of ice sheets in the high latitudes and a southward displacement of the westerly storm track in North America as it has also been suggested for the Last Glacial Maximum (Asmerom et al. 2010; Oster et al. 2015). During that time, the southward displacement of the westerly storm track caused a precipitation dipole in western North America, with wetter-thanpresent conditions in the southwestern United States and drier-than-modern conditions in the Pacific Northwest (including the Snake River Plain). Because the first continental 


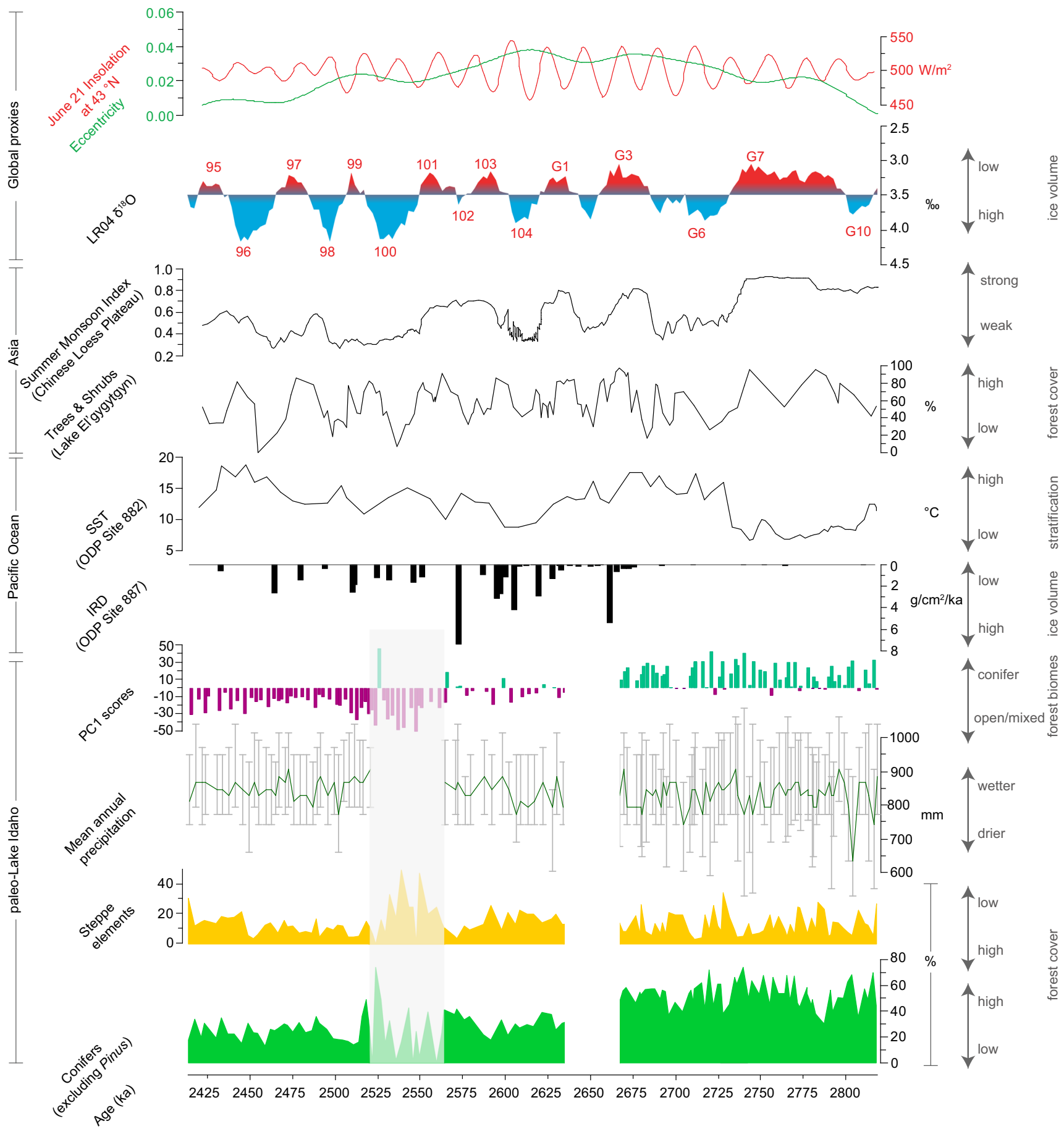

Fig. 5 Selected palynological data from the paleo-Lake Idaho record plotted against proxy data from the Pacific Ocean and Asia and global proxy data. IRD accumulation at ODP Site 887 after Prueher and Rea (2001), late summer sea-surface temperature (SST) reconstructions from ODP Site 882 after Haug et al. (2005), percentages of trees and shrubs

glaciations in North America were most likely less severe than the LGM, their impact on the position of the westerly storm track should have been weaker, hence restricting its displacement to within the northwestern United States. This mechanism could well explain the shift to wetter conditions during from Lake El'gygytgyn after Brigham-Grette et al. (2013), East Asian summer monsoon index from the Chinese Loess Plateau after Sun et al. (2010), LR04 global marine isotope stack after Lisiecki and Raymo (2005), eccentricity and summer insolation at $43^{\circ} \mathrm{N}$ after Laskar et al. (2004)

the iNHG in the western Snake River Plain. Support for such a scenario comes from a study that compiled the extent of past lakes in the western United States during the Last Glacial Maximum and coupled lake mass-balance equations with a water- and energy-balance framework (Ibarra et al. 2018). 
The results of that study suggest that during times of colder conditions of the Plio/Pleistocene the western United States experienced wetter conditions due to increased precipitation and decreased evaporative demand.

The influence of ocean-circulation dynamics on terrestrial climates and environmental conditions in mid-latitudinal western North America across the Plio/Pleistocene transition is further supported by the close coupling of the PC1 scores of our pollen dataset with marine-based proxy records from the North Pacific (Ocean Drilling Program [ODP] Site 887) and the California Margin (ODP Site 1014). Specifically, the timing of the change in the forest biomes at paleo-Lake Idaho at $\sim 2.6 \mathrm{Ma}$ is consistent with the onset of IRD deposition at Site 887 in the North Pacific (Prueher and Rea 2001; Figs. 1, 5), which supports the view that the change in forest biomes was climatically driven. Moreover, the shift in forest composition at paleo-Lake Idaho falls within an interval of major surface-water cooling and carbonate-productivity increase between 3.0 and $2.5 \mathrm{Ma}$ at the California Margin that indicates a reorganisation of the thermocline in the midlatitudinal eastern Pacific (Ravelo et al. 2004). On a hemisphere-wide scale, the comparison of our data from paleo-Lake Idaho with other records from North America and Asia points towards the development of a climatic dipole between drier eastern Asia and wetter western North America since the latest Pliocene.

Glacial/interglacial variability in the paleo-Lake Idaho record

Superimposed on the long-term vegetation trend towards a more open forest biome in the latest Pliocene as described above, several forest-contraction events documented by drops in tree-pollen percentages occur throughout the MHAFB11 pollen record (Fig. 3). These forest contractions are characterised by declines in tree-pollen percentages (with the exception of Pinus) and coeval increases in the percentages of herbaceous taxa, including typical steppe taxa such as Amaranthaceae and Artemisia. A similar picture emerges from a lower resolution pollen record from the western Snake River Plain (Thompson 1996).

The Multitaper (MTM) and REDFIT spectral analyses of the arboreal pollen record show a dominant cycle of c. 40 $22 \mathrm{~m}$ bandwidth for the interval from $733 \mathrm{~m}$ to $624 \mathrm{~m}$ (Supplementary Figs. 4 and 5). Based on an average sedimentation rate of $\sim 72 \mathrm{~cm} / \mathrm{kyr}$ as resulting from our age model, this cycle corresponds to a $\sim 55-31-k y r$ period, which resembles the orbital obliquity period (Laskar et al. 2004). Additionally, the results show a dominant 9-7-m cycle (corresponding to a 13-10 kyr cycle in the time domain) that could potentially represent the half-precession cycle. A similar pattern also emerges for the younger interval between 600 to $440 \mathrm{~m}$; here, the spectral analyses yielded a dominant 33-20-m cycle and a 13-7-m cycle, respectively (Supplementary Figs. 4 and 5). Based on an average sedimentation rate of $\sim 72 \mathrm{~cm} / \mathrm{kyr}$, these cycles correspond to 46-28-kyr and 15-10-kyr periods in the time domain, thereby also resembling orbital obliquity and half a precession period, respectively.

The dominant role of obliquity in both intervals is best attributed to the influence of glacial/interglacial changes on the moisture regime and, by extension, on vegetation at paleo-Lake Idaho. This is based on the fact that during the investigated time interval across the Plio/Pleistocene transition (i.e. 2.8-2.4 Ma) glacial/interglacial changes followed a persistent obliquity beat (Lisiecki and Raymo 2005).

Although tree-pollen percentages decreased substantially during glacial times at paleo-Lake Idaho, there are no signs of large-scale forest collapses. This situation contrasts markedly with that in the Yukon Territory $\left(65^{\circ} \mathrm{N}\right.$; Fig. 1), where closed boreal forests were replaced by steppe-tundra vegetation during glacial times during the late Pliocene and early Pleistocene (Schweger 1997; Schweger et al. 2011). Hence, there may have been a strong temperature gradient between the mid and high latitudes of northwestern North America during late Pliocene/early Pleistocene glacials. This gradient can be explained by the extent of ice-sheets in North America during that time. Specifically, moraines and till records from northern Canada and Alaska imply widespread glaciations in the high latitudes during the Pliocene, with a Cordilleran Ice Sheet occasionally migrating southward to $\sim 50^{\circ} \mathrm{N}$ during peak glacial times (Barendregt and Duk-Rodkin 2004; Gillespie et al. 2003; Ehlers and Gibbard 2007). However, larger scale ice sheets are thought to not have existed in mid-latitudes of North America during the Pliocene and early Pleistocene (Barendregt and Duk-Rodkin 2004), and only minor mountain glaciers were likely present occasionally during the late Pliocene (Dalrymple 1963; Gillespie and Clark 2011). In light of this ice-sheet distribution in North America, the extent of higher-latitude ice sheets was likely responsible for cooler conditions compared with ice-free mid-latitudes; by extension, their distribution also explains the markedly different vegetation patterns as documented by mid- versus highlatitude glacial pollen records from northwestern North America.

The only partial reduction in forest cover in glacial times seems to be a consistent feature of Northern Hemisphere midlatitude settings during the late Pliocene and early Pleistocene. Specifically, palynological evidence from Lake Baikal (Central Asia; Fig. 1) suggests that the lake catchment was covered by boreo-alpine forests during glacial times of the late Pliocene and early Pleistocene (Demske et al. 2002). Palynological records from northwestern Europe and the North Sea Basin indicate a transition from mixed mesophytic forests during the late Pliocene to boreal forests and tundra biomes during the early Pleistocene (e.g. Van der Hammen 1971; Zagwijn 1985; Donders et al. 2018). Well-expressed 
glacial/interglacial cycles with major increases of steppe elements at the expense of forest biomes are not recorded before 2.6 Ma in southern Europe (Combourieu-Nebout et al. 2015). Based on the available data, total forest collapses during glacial periods occurred in mid-latitude settings of the Northern Hemisphere only from the late early Pleistocene onwards. This notion is further supported by the $\sim 1$.4-Ma-long palynological records from Tenaghi Philippon (Pross et al. 2015) and Lake Ohrid (Wagner et al. 2019) in SE Europe; they show that a dominance of steppe vegetation and minimum forest cover was only reached during middle Pleistocene glaciations (e.g. van der Wiel and Wijmstra 1987a, b; Koutsodendris et al. 2012; Fletcher et al. 2013) when Northern Hemisphere ice sheets reached their maximum extent (e.g. McManus et al. 1999; Gillespie and Clark 2011; Barendregt and DukRodkin 2004; Gillespie et al. 2003; Barker et al. 2019).

Considering that the pollen record from paleo-Lake Idaho shows glacial/interglacial variability, the interval between 550 and $520 \mathrm{~m}$ merits special attention. It is consistently characterised by low pollen concentrations (Fig. 3). At first glance, the low pollen yield seems to be related to the deposition of muddy sands of the Tuana Gravel (Fig. 2). However, as indicated by the integration of our PCA results with the results of earlier geological studies on the western Snake River Plain (Repenning et al. 1994; Wood and Clemens 2002), a geomorphologically driven lake-level lowering occurred already further downcore at $\sim 2.7 \mathrm{Ma}$, within the Glenns Ferry Fm, thus substantially pre-dating the deposition of muddy sands. Hence, the deposition of the Tuana Gravel may well have been partially climatically driven. Such a scenario is further supported by the observation that the Tuana Gravel is overlain by the fine-grained lacustrine deposits of the Bruneau Fm, and its relatively short-lived deposition is somewhat difficult to reconcile with geomorphological or tectonic processes that would be expected to have operated on longer time scales.

In any case, even if the significance of our pollen data from that interval is limited by relatively low counting sums, the available data show clearly a strong increase in the percentages of steppe elements and a synchronous drop in the percentages of coniferous taxa (Figs. 2, 3). This signal likely indicates a strong climatic deterioration during the time of deposition. The increases in steppe elements at the expense of coniferous taxa are more extreme than in the older and younger parts of the succession, with steppe elements reaching abundances of $>40 \%$ (Fig. 3 ), a pattern that could represent a signal of glacial/interglacial cycles.

Based on our current linear age model, this cold interval may correspond to one of the early glacial periods of the Matuyama reversed polarity chron. A likely candidate for such a glacial is MIS $100(2.54-2.51 \mathrm{Ma}$; Lisiecki and Raymo 2005), which is known to have caused massive environmental change on a global scale. In North America, it likely led to the first advance of the Laurentide Ice Sheet into the mid-latitudes (Balco and Rovey, 2010).

In the marine realm, MIS 100 is characterised by increased global benthic $\delta^{18} \mathrm{O}$ values providing evidence for a build-up of ice-sheets (e.g. Lawrence et al. 2006). Consistent with larger ice volume, higher magnetic susceptibility values at ODP Sites 882 and 887 in the subarctic northwestern and northeastern Pacific document an intensification of ice-rafted debris transport during that time (Prueher and Rea 2001; Haug et al. 2005).

The first major glaciation of the early Pleistocene also left a strong imprint on terrestrial ecosystems. In the Qaidam paleolake on the NE Tibetan Plateau (Fig. 1), this interval has been connected to the deposition of evaporitic layers under enhanced dry conditions (Kaboth-Bahr et al. 2020) related to the intensification of the winter monsoon (An et al. 2012; Herb et al. 2015). At Lake Baikal, a major advance of steppe vegetation occurred during MIS 100, documenting severe glacial climate conditions (Demske et al. 2002). At more northern latitudes, the expansion of steppe biomes at Lake El'gygytgyn during that time developed for the first time during the Pleistocene, due to severely cold and dry climate conditions (Tarasov et al. 2013; Herzschuh et al. 2016). In view of the above and despite the present age-model uncertainties of the MHAFB11 core record, it appears likely that the vegetation change at paleo-Lake Idaho during the 2.6-2.5-Ma interval represents the response of terrestrial ecosystems in midlatitudinal settings of northwestern North America during the first major glaciation of the Pleistocene. By extension, this could be the first record documenting a strong impact of the MIS 100 glacial on terrestrial ecosystems in North America.

\section{Conclusions}

A new palynological record has been generated for the late Pliocene to early Pleistocene (c. 2.8-2.4 Ma) based on drillcore material from paleo-Lake Idaho (USA). Augmented by quantitative pollen-based climate estimates, it provides new insight into the characteristics of climate and terrestrial ecosystem variability in northwestern North America during the intensification of Northern Hemisphere glaciation. Our data suggest that forest dynamics were predominantly driven by climate change, likely including glacial/interglacial variability, as a response to orbital obliquity forcing. Importantly, the new pollen record from paleoLake Idaho documents a climatically driven forest biome change across the Plio/Pleistocene boundary, which is marked by the replacement of conifer-dominated forests by open mixed forests. This change is related to an increase in moisture availability. On a Northern-Hemisphere-wide scale, it contradicts the enhancement of dry conditions as documented in numerous climate archives from central and northeastern Asia. This points towards the development of a climatic dipole between central and northeastern 
Asia and western North America in the latest Pliocene, which is in agreement with the hypothesis that moisture transport to the high latitudes of North America increased at that time due to palaeoceanographic changes in the subarctic Pacific Ocean. In addition, the estimated timing of forest-composition change at paleo-Lake Idaho at $\sim 2.6 \mathrm{Ma}$ is consistent with the onset of IRD deposition in the North Pacific and a surface-temperature drop at the California Margin. Altogether, the close correspondence between our palynological data from paleo-Lake Idaho and available marine proxy records from the NE Pacific suggests a close coupling of terrestrial ecosystem changes in North America to Pacific Ocean circulation dynamics across the Plio/ Pleistocene boundary.

Acknowledgements Kim Jakob and Kai Nakajima are thanked for helpful discussions. Malcolm Jones and Jamal Joud provided technical assistance. We thank the reviewers of our manuscript for their constructive comments. We are also grateful for the invitation to contribute to this special issue by the guest-editors Angela Bruch, Dieter Uhl and Torsten Utescher.

Authors' contributions Jörg Pross, Andreas Koutsodendris, Alexander Prokopenko and Erwin Appel designed the study. Palynological analyses and data interpretation were performed by Frederik Allstädt with the support of Andreas Koutsodendris, Jörg Pross and Stefanie KabothBahr. Palaeomagnetic analyses were carried out by Frederik Allstädt, Erwin Appel and Wolfgang Rösler. Alexander Prokopenko organised and led the core opening campaign, delivered the core to Germany, provided initial core data, developed depth scales and participated in sampling and handling of the core, including personally drilling out the oriented core plugs for the palaeomagnetic measurements newly reported in the paper. Quantitative climate estimates were generated by Tammo Reichgelt. Frederik Allstädt, Andreas Koutsodendris and Jörg Pross wrote the manuscript with input from all co-authors.

Funding Open Access funding enabled and organized by Projekt DEAL. This study was financially supported by the German Research Foundation (DFG; grants AP 34/46-1 and 48-1, and PR 1404/3-1, and PR 651/20 to EA, AP, and JP, respectively) within the framework of the DFG ICDP priority program.

Data availability All data generated and analysed during this study are included in supplementary information files.

\section{Compliance with ethical standards}

Conflict of interest The authors declare that they have no conflict of interest.

Open Access This article is licensed under a Creative Commons Attribution 4.0 International License, which permits use, sharing, adaptation, distribution and reproduction in any medium or format, as long as you give appropriate credit to the original author(s) and the source, provide a link to the Creative Commons licence, and indicate if changes were made. The images or other third party material in this article are included in the article's Creative Commons licence, unless indicated otherwise in a credit line to the material. If material is not included in the article's Creative Commons licence and your intended use is not permitted by statutory regulation or exceeds the permitted use, you will need to obtain permission directly from the copyright holder. To view a copy of this licence, visit http://creativecommons.org/licenses/by/4.0/.

\section{References}

Allstädt, F. J., Appel, E., Rösler, W., Prokopenko, A. A., Neumann, U., Wenzel, T., \& Pross, J. (2020). Downward remagnetization of a $\sim 74$ $\mathrm{m}$ thick zone in lake sediments from paleo-Lake Idaho (NW United States) - locating the Gauss/Matuyama geomagnetic boundary within a dual-polarity interval. Geophysical Journal International, 222, 754-768.

An, Z., Kutzbach, J. E., Prell, W. L., \& Porter, S. C. (2001). Evolution of Asian monsoons and phased uplift of the Himalaya-Tibetan plateau since Late Miocene times. Nature, 411, 62-66.

An, Z., Colman, S. M., Zhou, W., Li, X., Brown, E. T., Jull, A. J. T., Cai, Y., Huang, Y., Lu, X., Chang, H., et al. (2012). Interplay between the Westerlies and Asian monsoon recorded in Lake Qinghai sediments since $32 \mathrm{ka}$. Scientific Reports, 2, 1-7.

Anderson, J. E., \& Holte, K. E. (1981). Vegetation development over 25 years without grazing on sagebrush-dominated rangeland in Southeastern Idaho. Journal of Range Management, 34, 25.

Armstrong, R. L., Leeman, W. P., \& Malde, H. E. (1975). K-Ar dating Quaternary and Neogene volcanic rocks of the Snake River Plain, Idaho. American Journal of Science, 275, 225-251.

Asmerom, Y., Polyak, V. J., \& Burns, S. J. (2010). Variable winter moisture in the southwestern United States linked to rapid glacial climate shifts. Nature Geoscience, 3, 114-117.

Bailey, I., Hole, G. M., Foster, G. L., Wilson, P. A., Storey, C. D., Trueman, C. N., \& Raymo, M. E. (2013). An alternative suggestion for the Pliocene onset of major northern hemisphere glaciation based on the geochemical provenance of North Atlantic Ocean ice-rafted debris. Quaternary Science Reviews, 75, 181-194.

Balco, G., \& Rovey, C. W. (2010). Absolute chronology for major Pleistocene advances of the Laurentide Ice Sheet. Geology, 38, 795-798.

Barendregt, R. W., \& Duk-Rodkin, A. (2004). Chronology and extent of Late Cenozoic ice sheets in North America: a magnetostratigraphic assessment. In J. Ehlers \& P. L. Gibbard (Eds.), Developments in Quaternary Sciences (pp. 1-7). Elsevier.

Barker, S., Knorr, G., Conn, S., Lordsmith, S., Newman, D., \& Thornalley, D. (2019). Early interglacial legacy of deglacial climate instability. Paleoceanography and Paleoclimatology, 34, 14551475.

Bartoli, G., Sarnthein, M., \& Weinelt, M. (2006). Late Pliocene millennial-scale climate variability in the northern North Atlantic prior to and after the onset of Northern Hemisphere glaciation. Paleoceanography, 21, PA4205.

Bennett, K. D. (1996). Determination of the number of zones in a biostratigraphical sequence. New Phytologist, 132, 155-170.

Bolton, C. T., Gibbs, S. J., \& Wilson, P. A. (2010). Evolution of nutricline dynamics in the equatorial Pacific during the late Pliocene. Paleoceanography, 25, PA1207.

Brigham-Grette, J., Melles, M., Minyuk, P., Andreev, A., Tarasov, P., DeConto, R., Koenig, S., Nowaczyk, N., Wennrich, V., Rosén, P., Haltia, E., Cook, T., Gebhardt, C., Meyer-Jacob, C., Snyder, J., \& Herzschuh, U. (2013). Pliocene warmth, polar amplification, and stepped Pleistocene cooling recorded in NE Arctic Russia. Science, 340, 1421-1427.

Bright, R. C., \& Davis, O. K. (1982). Quaternary Paleoecology of the Idaho National Engineering Laboratory, Snake River Plain, Idaho. American Midland Naturalist, 108, 21.

Bryson, R. A. (1965). Air masses, streamlines, and the boreal forest. Geographical Bulletin, 8, 228-269.

Canty, J. L., Frischling, B., \& Frischling, D. (2020). Weatherbase. http:// www.weatherbase.com. Accessed 28.02.2020.

Chadima, M., \& Hrouda, F. (2006). Remasoft 3.0 a user-friendly paleomagnetic data browser and analyzer. Travaux Géophysiques, 27, $20-21$. 
Combourieu-Nebout, N., Bertini, A., Russo-Ermolli, E., Peyron, O., Klotz, S., Montade, V., Fauquette, S., Allen, J., Fusco, F., Goring, S., Huntley, B., Joannin, S., Lebreton, V., Magri, D., Martinetto, E., Orain, R., \& Sadori, L. (2015). Climate changes in the Central Mediterranean and Italian vegetation dynamics since the Pliocene. Review of Palaeobotany and Palynology, 218, 127-147.

Dalrymple, G. B. (1963). Potassium-argon dates of some Cenozoic volcanic rocks of the Sierra Nevada, California. Geological Society of America Bulletin, 74, 379-390.

Davis, O. K., \& Moutoux, T. E. (1998). Tertiary and Quaternary vegetation history of the Great Salt Lake, Utah, USA. Journal of Paleolimnology, 19, 417-427.

DeConto, R. M., Pollard, D., Wilson, P. A., Pälike, H., Lear, C. H., \& Pagani, M. (2008). Thresholds for Cenozoic bipolar glaciation. Nature, 455, 652-656.

De Schepper, S., Gibbard, P. L., Salzmann, U., \& Ehlers, J. (2014). A global synthesis of the marine and terrestrial evidence for glaciation during the Pliocene Epoch. Earth-Science Reviews, 135, 83-102.

Demske, D., Mohr, B., \& Oberhänsli, H. (2002). Late Pliocene vegetation and climate of the Lake Baikal region, southern East Siberia, reconstructed from palynological data. Palaeogeography, Palaeoclimatology, Palaeoecology, 184, 107-129.

Ding, Z. L., Xiong, S. F., Sun, J. M., Yang, S. L., Gu, Z. Y., \& Liu, T. S. (1999). Pedostratigraphy and paleomagnetism of a $\sim 7.0$ Ma eolian loess-red clay sequence at Lingtai, Loess Plateau, north-central China and the implications for paleomonsoon evolution. Palaeogeography, Palaeoclimatology, Palaeoecology, 152, 49-66.

Dixon, M. D., \& Johnson, W. C. (1999). Riparian vegetation along the middle Snake River, Idaho: zonation, geographical trends, and historical changes. Great Basin Naturalist, 59, 18-34.

Donders, T. H., van Helmond, N. A. G. M., Verreussel, R., Munsterman, D., ten Veen, J., Speijer, R. P., Weijers, J. W. H., Sangiorgi, F., Peterse, F., Reichart, G.-J., Sinninghe Damsté, J. S., Lourens, L., Kuhlmann, G., \& Brinkhuis, H. (2018). Land-sea coupling of early Pleistocene glacial cycles in the southern North Sea exhibit dominant Northern Hemisphere forcing. Climate of the Past, 14, 397411.

Driscoll, N. W., \& Haug, G. H. (1998). A short circuit in thermohaline circulation: a cause for Northern Hemisphere glaciation? Science, $282,436-438$.

Ehlers, J., \& Gibbard, P. L. (2007). The extent and chronology of Cenozoic global glaciation. Quaternary International, 164-165, 6-20.

Ekren, E., McIntyre, D., Bennett, E., \& Malde, H. (1981). Geologic map of Owyhee County, Idaho, west of longitude $116^{\circ} \mathrm{W}$, U.S. Geological Survey.

Fick, S. E., \& Hijmans, R. J. (2017). WorldClim 2: new 1-km spatial resolution climate surfaces for global land areas. International Journal of Climatology, 37, 4302-4315.

Fletcher, W. J., Müller, U. C., Koutsodendris, A., Christanis, K., \& Pross, J. (2013). A centennial-scale record of vegetation and climate variability from 312 to $240 \mathrm{ka}$ (marine isotope stages $9 \mathrm{c}-\mathrm{a}, 8$ and $7 \mathrm{e}$ ) from Tenaghi Philippon, NE Greece. Quaternary Science Reviews, $78,108-125$.

Gavin, D. G., \& Hu, F. S. (2006). Spatial variation of climatic and nonclimatic controls on species distribution: the range limit of Tsuga heterophylla. Journal of Biogeography, 33, 1384-1396. https:// www.gbif.org. Accessed 19 Dec 2019.

Gillespie, A. R., Porter, S. C., \& Atwater, B. F. (2003). The Quaternary Period in the United States. Amsterdam: Elsevier.

Gillespie, A. R., \& Clark, D. H. (2011). Chapter 34 - Glaciations of the Sierra Nevada, California, USA. In E. Jürgen, P. L. Gibbard, \& P. D. Hughes (Eds.), Developments in Quaternary Sciences (Vol. 15, pp. 447-462). Elsevier.
Grimm, E. C. (1987). CONISS: a FORTRAN 77 program for stratigraphically constrained cluster analysis by the method of incremental sum of squares. Computers \& Geosciences, 13, 13-35.

Grimm, G. W., \& Potts, A. J. (2016). Fallacies and fantasies: the theoretical underpinnings of the coexistence approach for palaeoclimate reconstruction. Climate of the Past, 12, 611-622.

Hammen, T. van der (1971). The floral record of the Late Cenozoic of Europe. In K. K. Turekian (Ed.), Late Cenozoic glacial ages (pp. 391-424). New Haven: Yale University Press.

Hammer, Ø., Harper, D. A. T., \& Ryan, P. D. (2001). PAST: Paleontological statistics software package for education and data analysis. Palaeontologia Electronica, 4, 9.

Haug, G. H., \& Tiedemann, R. (1998). Effect of the formation of the Isthmus of Panama on Atlantic Ocean thermohaline circulation. Nature, 393, 673-676.

Haug, G. H., Sigman, D. M., Tiedemann, R., Pedersen, T. F., \& Sarnthein, M. (1999). Onset of permanent stratification in the subarctic Pacific Ocean. Nature, 401, 779-782.

Haug, G. H., Ganopolski, A., Sigman, D. M., Rosell-Mele, A., Swann, G. E. A., Tiedemann, R., Jaccard, S. L., Bollmann, J., Maslin, M. A., Leng, M. J., \& Eglington, G. (2005). North Pacific seasonality and the glaciation of North America 2.7 million years ago. Nature, 433, $821-825$

Haywood, A. M., Dowsett, H. J., \& Dolan, A. M. (2016). Integrating geological archives and climate models for the mid-Pliocene warm period. Nature Communications, 7, 10646.

Herb, C., Koutsodendris, A., Zhang, W., Appel, E., Fang, X., Voigt, S., \& Pross, J. (2015). Late Plio-Pleistocene humidity fluctuations in the western Qaidam Basin (NE Tibetan Plateau) revealed by an integrated magnetic-palynological record from lacustrine sediments. Quaternary Research, 84, 457-466.

Herzschuh, U., Birks, H. J. B., Laepple, T., Andreev, A., Melles, M., \& Brigham-Grette, J. (2016). Glacial legacies on interglacial vegetation at the Pliocene-Pleistocene transition in NE Asia. Nature Communications, 7, 11967.

Hijmans, R. J., Cameron, S. E., Parra, J. L., Jones, P. G., \& Jarvis, A. (2005). Very high resolution interpolated climate surfaces for global land areas. International Journal of Climatology, 25, 1965-1978.

Hyland, E. G., Huntington, K. W., Sheldon, N. D., \& Reichgelt, T. (2018). Temperature seasonality in the North American continental interior during the Early Eocene Climatic Optimum. Climate of the Past, 14, 1391-1404.

Ibarra, D. E., Oster, J. L., Winnick, M. J., Caves Rugenstein, J. K., Byrne, M. P., \& Chamberlain, C. P. (2018). Warm and cold wet states in the western United States during the Pliocene-Pleistocene. Geology, 46, $355-358$.

Juggins, S. (2017). Rioja: Analysis of quaternary science data. R Package Version, pp., 5-6.

Kaboth-Bahr, S., Koutsodendris, A., Lu, Y., Nakajima, K., Zeeden, C., Appel, E., Fang, X., Rösler, W., Friedrich, O., \& Pross, J. (2020). A late Pliocene to early Pleistocene (3.3-2.1 Ma) orbital chronology for the Qaidam Basin paleolake (NE Tibetan Plateau) based on the SG-1b drillcore record. Newsletters on Stratigraphy, 53, 479-496.

Keigwin, L. (1982). Isotopic Paleoceanography of the Caribbean and East Pacific: Role of Panama uplift in Late Neogene time. Science, 217, 350-353.

Kimmel, P. G. (1982). Stratigraphy, age, and tectonic setting of the Miocene-Pliocene lacustrine sediments of the western Snake River Plain, Oregon and Idaho. Cenozoic geology of Idaho: Idaho Bureau of Mines and Geology Bulletin, 26, 559-578.

Kirschvink, J. L. (1980). The least-squares line and plane and the analysis of palaeomagnetic data. Geophysical Journal International, 62, 699-718.

Köppen, W. (1900). Versuch einer Klassifikation der Klimate, vorzugsweise nach ihren Beziehungen zur Pflanzenwelt. Geographische Zeitschrift, 6, 657-679. 
Koutsodendris, A., Allstädt, F. J., Kern, O. A., Kousis, I., Schwarz, F., Vannacci, M., Woutersen, A., Appel, E., Berke, M. A., Fang, X., Friedrich, O., Hoorn, C., Salzmann, U., \& Pross, J. (2019a). Late Pliocene vegetation turnover on the NE Tibetan Plateau (Central Asia) triggered by early Northern Hemisphere glaciation. Global and Planetary Change, 180, 117-125.

Koutsodendris, A., Kousis, I., Peyron, O., Wagner, B., \& Pross, J. (2019b). The Marine Isotope Stage 12 pollen record from Lake Ohrid (SE Europe): Investigating short-term climate change under extreme glacial conditions. Quaternary Science Reviews, 221, 105873 .

Koutsodendris, A., Pross, J., Müller, U. C., Brauer, A., Fletcher, W. J., Kühl, N., Kirilova, E., Verhagen, F. T. M., Lücke, A., \& Lotter, A. F. (2012). A short-term climate oscillation during the Holsteinian interglacial (MIS 11c): an analogy to the $8.2 \mathrm{ka}$ climatic event? Global and Planetary Change, 92-93, 224-235.

Laskar, J., Robutel, P., Joutel, F., Gastineau, M., Correia, A. C. M., \& Levrard, B. (2004). A long-term numerical solution for the insolation quantities of the Earth. Astronomy \& Astrophysics, 428, 261285.

Lawrence, K. T., Liu, Z., \& Herbert, T. D. (2006). Evolution of the eastern tropical Pacific through Plio-Pleistocene glaciation. Science, 312, 79-83.

Lisiecki, L. E., \& Raymo, M. E. (2005). A Pliocene-Pleistocene stack of 57 globally distributed benthic $\delta^{18} \mathrm{O}$ records. Paleoceanography, 20, PA1003.

Lunt, D. J., Foster, G. L., Haywood, A. M., \& Stone, E. J. (2008). Late Pliocene Greenland glaciation controlled by a decline in atmospheric $\mathrm{CO}_{2}$ levels. Nature, 454, 1102-1105.

Malde, H. E. (1991). Quaternary geology and structural history of the Snake River Plain, Idaho and Oregon. The Geology of North America, 2, 251-281.

Malde, H. E., \& Powers, H. A. (1962). Upper Cenozoic stratigraphy of western Snake River Plain, Idaho. Geological Society of America Bulletin, 73, 1197-1220.

Martinez, M., Kotov, S., De Vleeschouwer, D., Pas, D., \& Pälike, H. (2016). Testing the impact of stratigraphic uncertainty on spectral analyses of sedimentary series. Climate of the Past, 12, 1765-1783.

Martínez-Botí, M. A., Foster, G. L., Chalk, T. B., Rohling, E. J., Sexton, P. F., Lunt, D. J., Pancost, R. D., Badger, M. P. S., \& Schmidt, D. N. (2015). Plio-Pleistocene climate sensitivity evaluated using highresolution $\mathrm{CO}_{2}$ records. Nature, 518, 49-54.

McCurry, M., Bonnichsen, B., White, C., Godchaux, M. M., \& Hughes, S. S. (1997). Bimodal basalt-rhyolite magmatism in the central and western Snake River Plain, Idaho and Oregon. Brigham Young University Geology Studies, 42, 381-422.

McManus, J. F., Oppo, D. W., \& Cullen, J. L. (1999). A 0.5-million-year record of millennial-scale climate variability in the North Atlantic. Science, 283, 971-975.

Morgan, L. A. (1992). Stratigraphic relations and paleomagnetic and geochemical correlations of ignimbrites of the Heise volcanic field, eastern Snake River Plain, eastern Idaho and western Wyoming. In P. K. Link, M. A. Kuntz, \& L. B. Platt (Eds.), Regional Geology Of Eastern Idaho and Western Wyoming (Vol. 179, pp. 215-226) Geological Society of America.

Mosbrugger, V., \& Utescher, T. (1997). The coexistence approach - a method for quantitative reconstructions of Tertiary terrestrial palaeoclimate data using plant fossils. Palaeogeography, Palaeoclimatology, Palaeoecology, 134, 61-86.

Mudelsee, M., \& Raymo, M. E. (2005). Slow dynamics of the Northern Hemisphere glaciation. Paleoceanography, 20, PA4022.

Müller, U. C., Pross, J., \& Bibus, E. (2003). Vegetation response to rapid climate change in Central Europe during the past 140,000 yr based on evidence from the Füramoos pollen record. Quaternary Research, 59, 235-245.
Neville, C., Opdyke, N. D., Lindsay, E. H., \& Johnson, N. M. (1979). Magnetic stratigraphy of Pliocene deposits of the Glenns Ferry Formation, Idaho, and its implications for North American mammalian biostratigraphy. American Journal of Science, 279, 503-526.

Ogg, J. G. (2012). Geomagnetic polarity time scale. In F. M. Gradstein (Ed.), The geologic time scale (pp. 85-113). Amsterdam, Boston: Elsevier.

Oster, J. L., Ibarra, D. E., Winnick, M. J., \& Maher, K. (2015). Steering of westerly storms over western North America at the Last Glacial Maximum. Nature Geoscience, 8, 201-205.

Othberg, K. L. (1994). Geology and geomorphology of the Boise Valley and adjoining areas, western Snake River Plain, Idaho. Idaho Geological Survey Bulletin, 29, 1-54.

Pachauri, R. K., Allen, M. R., Barros, V. R., Broome, J., Cramer, W., Christ, R., Church, J. A., Clarke, L., Dahe, Q., Dasgupta, P. et al. (2014). Climate change 2014: synthesis report. Contribution of Working Groups I, II and III to the fifth assessment report of the Intergovernmental Panel on Climate Change IPCC, Geneva, Switzerland.

Perkins, M. E., Brown, F. H., Nash, W. P., Williams, S. K., \& McIntosh, W. (1998). Sequence, age, and source of silicic fallout tuffs in middle to late Miocene basins of the northern Basin and Range province. GSA Bulletin, 110, 344-360.

Pierce, K. L., Morgan, L. A., \& Link, P. (1992). The track of the Yellowstone hot spot: volcanism, faulting, and uplift. Regional geology of eastern Idaho and western Wyoming: Geological Society of America Memoir, 179, 1-53.

Pound, M. J., Lowther, R. I., Peakall, J., Chapman, R. J., \& Salzmann, U. (2015). Palynological evidence for a warmer boreal climate in the late Pliocene of the Yukon Territory, Canada. Palynology, 39, 91102.

Pross, J., \& Klotz, S. (2002). Palaeotemperature calculations from the Praetiglian/Tiglian (Plio-Pleistocene) pollen record of Lieth, northern Germany: implications for the climatic evolution of NW Europe. Global and Planetary Change, 34, 253-267.

Pross, J., Klotz, S., \& Mosbrugger, V. (2000). Reconstructing palaeotemperatures for the Early and Middle Pleistocene using the mutual climatic range method based on plant fossils. Quaternary Science Reviews, 19, 1785-1799.

Pross, J., Koutsodendris, A., Christanis, K., Fischer, T., Fletcher, W. J., Hardiman, M., Kalaitzidis, S., Knipping, M., Kotthoff, U., Milner, A. M., Müller, U. C., Schmiedl, G., Siavalas, G., Tzedakis, P. C., \& Wulf, S. (2015). The 1.35-Ma-long terrestrial climate archive of Tenaghi Philippon, northeastern Greece: Evolution, exploration, and perspectives for future research. Newsletters on Stratigraphy, $48,253-276$

Prueher, L. M., \& Rea, D. K. (2001). Volcanic triggering of late Pliocene glaciation: evidence from the flux of volcanic glass and ice-rafted debris to the North Pacific Ocean. Palaeogeography, Palaeoclimatology, Palaeoecology, 173, 215-230.

Ravelo, A. C., Andreasen, D. H., Lyle, M., Lyle, A. O., \& Wara, M. W. (2004). Regional climate shifts caused by gradual global cooling in the Pliocene epoch. Nature, 429, 263-267.

Repenning, C. A., Weasma, T. R., \& Scott, G. R. (1994). The early Pleistocene (latest Blancan-earliest Irvingtonian) Froman Ferry fauna and history of the Glenns Ferry Formation, southwestern Idaho. U.S. Geological Survey Bulletin, 2105, 1-86.

Robinson, M. M., Dowsett, H. J., \& Chandler, M. A. (2008). Pliocene role in assessing future climate impacts. Eos, Transactions American Geophysical Union, 89, 501-502.

Ruddiman, W. F., \& Kutzbach, J. E. (1989). Forcing of late Cenozoic northern hemisphere climate by plateau uplift in southern Asia and the American West. Journal of Geophysical Research: Atmospheres, 94, 18409-18427. 
Sadler, J. L., \& Link, P. K. (1996). The Tuana gravel; early Pleistocene response to longitudinal drainage of a late-stage rift basin, western Snake River plain, Idaho. Northwestern Geology, 26, 46-62.

Salzmann, U., Dolan, A. M., Haywood, A. M., Chan, W.-L., Voss, J., Hill, D. J., Abe-Ouchi, A., Otto-Bliesner, B., Bragg, F. J., Chandler, M. A., Contoux, C., Dowsett, H. J., Jost, A., Kamae, Y., Lohmann, G., Lunt, D. J., Pickering, S. J., Pound, M. J., Ramstein, G., Rosenbloom, N. A., Sohl, L., Stepanek, C., Ueda, H., \& Zhang, Z. (2013). Challenges in quantifying Pliocene terrestrial warming revealed by data-model discord. Nature Climate Change, 3, 969-974.

Schulz, M., \& Mudelsee, M. (2002). REDFIT: estimating red-noise spectra directly from unevenly spaced paleoclimatic time series. Computers \& Geosciences, 28, 421-426.

Schweger, C. E. (1997). Late Quaternary Palaeoecology of the Yukon: a review. In J. A. Danks (Ed.), Insects of the Yukon (Vol. 2, pp. 59-72) Biological Survey of Canada Monograph series.

Schweger, C., Froese, D., White, J. M., \& Westgate, J. A. (2011). Preglacial and interglacial pollen records over the last $3 \mathrm{Ma}$ from northwest Canada: Why do Holocene forests differ from those of previous interglaciations? Quaternary Science Reviews, 30, 2124-2133.

Shackleton, N. J., Backman, J., Zimmerman, H. T., Kent, D. V., Hall, M. A., Roberts, D. G., Schnitker, D., Baldauf, J. G., Desprairies, A., Homrighausen, R., \& Huddlestun, P. (1984). Oxygen isotope calibration of the onset of ice-rafting and history of glaciation in the North Atlantic region. Nature, 307, 620-623.

Shervais, J. W., \& Vetter, S. K. (2009). High-K alkali basalts of the Western Snake River Plain (Idaho): Abrupt transition from tholeiitic to mildly alkaline plume-derived basalts. Journal of Volcanology and Geothermal Research, 188, 141-152.

Shervais, J. W., Kauffman, J. D., Gillerman, V. S., Othberg, K. L., Vetter, S. K., Hobson, V. R., Zarnetske, M., Cooke, M. F., Matthews, S. H., \& Hanan, B. B. (2005). Basaltic volcanism of the central and western Snake River Plain: a guide to field relations between Twin Falls and Mountain Home, Idaho. In B. Bonnichsen, C. M. White, \& M. McCurry (Eds.), GSA Field Guide 6: Interior Western United States (Vol. 6, pp. 27-52) Geological Society of America.

Shervais, J. W., Branney, M. J., Geist, D. J., Hanan, B. B., Hughes, S., Prokopenko, A. A., \& Williams, D. F. (2006). HOTSPOT: the Snake River scientific drilling project-tracking the Yellowstone hotspot through space and time. Scientific Drilling, 3, 56-57.

Shervais, J. W., Schmitt, D. R., Nielson, D., Evans, J. P., Christiansen, E. H., Morgan, L., Shanks, W. C., Prokopenko, A. A., Lachmar, T., Liberty, L. M., Blackwell, D. D., Glen, J. M., Champion, D., Potter, K. E., \& Kessler, J. A. (2013). First results from HOTSPOT: The Snake River Plain scientific drilling project, Idaho, USA. Scientific Drilling, 15, 36-45.

Shinker, J. J., Bartlein, P. J., \& Shuman, B. (2006). Synoptic and dynamic climate controls of North American mid-continental aridity. Quaternary Science Reviews, 25, 1401-1417.

Smith, G. R., Morgan, N., \& Gustafson, E. (2000). Fishes of the MioPliocene Ringold Formation, Washington: Pliocene capture of the Snake River by the Columbia River. University of Michigan Publications in Paleontology, 32, 1-47.

Sun, Y., An, Z., Clemens, S. C., Bloemendal, J., \& Vandenberghe, J. (2010). Seven million years of wind and precipitation variability on the Chinese Loess Plateau. Earth and Planetary Science Letters, 297, 525-535.
Tarasov, P. E., Andreev, A. A., Anderson, P. M., Lozhkin, A. V., Leipe, C., Haltia, E., Nowaczyk, N. R., Wennrich, V., Brigham-Grette, J., \& Melles, M. (2013). A pollen-based biome reconstruction over the last 3.562 million years in the Far East Russian Arctic - new insights into climate-vegetation relationships at the regional scale. Climate of the Past, 9, 2759-2775.

Tassell, J. van., Ferns, M., McConnell, V., \& Smith, G. (2001). The midPliocene Imbler fish fossils, Grande Ronde Valley, Union County, Oregon, and the connection between Lake Idaho and the Columbia River. Oregon Geology, 63, 77-84.

Thomas, P. A., \& Polwart, A. (2003). Taxus baccata L. Journal of Ecology, 91, 489-524.

Thompson, R. S. (1991). Pliocene environments and climates in the western United States. Quaternary Science Reviews, 10, 115-132.

Thompson, R. S. (1996). Pliocene and early Pleistocene environments and climates of the western Snake River Plain, Idaho. Marine Micropaleontology, 27, 141-156.

Thomson, D. J. (1982). Spectrum estimation and harmonic analysis. Proceedings of the IEEE, 70, 1055-1096.

Wagner, B., Vogel, H., Francke, A., Friedrich, T., Donders, T., Lacey, J. H., Leng, M. J., Regattieri, E., Sadori, L., Wilke, T., Zanchetta, G., Albrecht, C., Bertini, A., Combourieu-Nebout, N., Cvetkoska, A., Giaccio, B., Grazhdani, A., Hauffe, T., Holtvoeth, J., Joannin, S., Jovanovska, E., Just, J., Kouli, K., Kousis, I., Koutsodendris, A., Krastel, S., Lagos, M., Leicher, N., Levkov, Z., Lindhorst, K., Masi, A., Melles, M., Mercuri, A. M., Nomade, S., Nowaczyk, N., Panagiotopoulos, K., Peyron, O., Reed, J. M., Sagnotti, L., Sinopoli, G., Stelbrink, B., Sulpizio, R., Timmermann, A., Tofilovska, S., Torri, P., Wagner-Cremer, F., Wonik, T., \& Zhang, X. (2019). Mediterranean winter rainfall in phase with African monsoons during the past 1.36 million years. Nature, 573, 256-260.

Wiel, A. M., van der., \& Wijmstra, T. A. (1987a). Palynology of the 112.8-197.8 m interval of the core Tenaghi Philippon III, Middle Pleistocene of Macedonia. Review of Palaeobotany and Palynology, $52,89-117$.

Wiel, A. M., van der., \& Wijmstra, T. A. (1987b). Palynology of the lower part (78-120 M) of the core Tenaghi Philippon II, Middle Pleistocene of Macedonia, Greece. Review of Palaeobotany and Palynology, 52, 73-88.

Willard, D. A., Donders, T. H., Reichgelt, T., Greenwood, D. R., Sangiorgi, F., Peterse, F., Nierop, K. G. J., Frieling, J., Schouten, S., \& Slujis, A. (2019). Arctic vegetation, temperature, and hydrology during Early Eocene transient global warming events. Global and Planetary Change, 178, 139-152.

Wood, S. H. (1994). Seismic expression and geological significance of a lacustrine delta in Neogene deposits of the western Snake River plain, Idaho. AAPG Bulletin, 78, 102-121.

Wood, S. H., \& Clemens, D. M. (2002). Geologic and tectonic history of the western Snake River Plain, Idaho and Oregon. Tectonic and Magmatic Evolution of the Snake River Plain Volcanic Province: Idaho Geological Survey Bulletin, 30, 69-103.

Zagwijn, W. H. (1985). An outline of the Quaternary stratigraphy of the Netherlands. Geologie en Mijnbouw, 64, 17-24.

Publisher's note Springer Nature remains neutral with regard to jurisdictional claims in published maps and institutional affiliations. 